\title{
¿Sila Qanuippa? (How's the Weather?): Integrating Inuit Qaujimajatuqangit and Environmental Forecasting Products to Support Travel Safety around Pond Inlet, Nunavut, in a Changing Climate
}

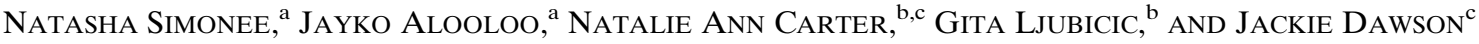 \\ a Pond Inlet, Nunavut, Canada \\ ${ }^{\mathrm{b}}$ School of Earth, Environment and Society, McMaster University, Hamilton, Ontario, Canada \\ ${ }^{\mathrm{c}}$ Department of Geography, Environment and Geomatics, University of Ottawa, Ottawa, Ontario, Canada
}

(Manuscript received 21 December 2020, in final form 27 July 2021)

\begin{abstract}
As Inuit hunters living in Pond Inlet, Nunavut, we (N. Simonee and J. Alooloo) travel extensively on land, water, and sea ice. Climate change, including changing sea ice and increasingly unpredictable weather patterns, has made it riskier and harder for us to travel and hunt safely. Inuit knowledge supporting safe travel is also changing and is shared less between generations. We increasingly use online weather, marine, and ice products to develop locally relevant forecasts. This helps us to make decisions according to wind, waves, precipitation, visibility, sea ice conditions, and floe edge location. We apply our forecasts and share them with fellow community members to support safe travel. In this paper, we share the approach that we developed from over a decade of systematically and critically assessing forecasting products such as Windy.com, weather and marine forecasts, tide tables, C-CORE's floe edge monitoring service, SmartICE, Zoom Earth, and time-lapse cameras. We describe the strengths and challenges we face when accessing, interpreting, and applying each product throughout different seasons. Our analysis highlights a disconnect between available products and local needs. This disconnect can be overcome by service providers adjusting services to include more seasonal and real-time information, nontechnical language, familiar units of measurement, data size proportional to internet access cost and speed, and clear relationships between weather, marine, and ice information and safe travel. Our findings have potential relevance in the circumpolar Arctic and beyond, wherever people combine Indigenous weather forecasting methods and online information for decision-making. We encourage service providers to improve product relevance and accessibility.

SIGNIFICANCE STATEMENT: As Inuit hunters in Pond Inlet, Nunavut, we combine our knowledge of environmental conditions with weather, marine, and ice forecasting products to travel safely. Products developed for urban environments or economic sectors are not directly relevant to our seasonal activities, so we have had to learn how to access and interpret them. Like other Indigenous peoples, we face challenges such as limited and expensive bandwidth, having to consult multiple sources, doing mathematical unit conversions, vague or unfamiliar terminology, and insufficient geographical coverage. We have worked hard to develop a clearer understanding of the relationships between information provided and our local travel conditions. Information services can help further by being more user-friendly, complete, and locally applicable to cultural and geographic context.
\end{abstract}

KEYWORDS: Arctic; Forecasting techniques; Climate variability; Adaptation; Climate services; Communications/decision making; Decision support; Indigenous knowledge; Risk assessment; Societal impacts

\section{Introduction}

We, N. Simonee and J. Alooloo, live in Pond Inlet, Nunavut, Canada $\left(72.7001^{\circ} \mathrm{N}, 77.9585^{\circ} \mathrm{W}\right)$, on the northern tip of Baffin Island (Fig. 1). We are Inuit (Indigenous Peoples in Arctic Canada) who travel extensively on land, ice, and across the open ocean in order to feed our families through subsistence hunting and to practice our Inuit culture. For decades we have been observing and assessing environmental indicators to be able to travel safely. In doing so we have developed our own way of forecasting the weather by combining Inuit Qaujimajatuqangit with available online weather, marine,

\footnotetext{
¿ Denotes content that is immediately available upon publication as open access.
}

Corresponding author: Natalie Ann Carter, ncarte3@uottawa.ca and ice products. Inuit Qaujimajatuqangit is a term often used by the government of Nunavut and in academic publications to refer to Inuit values and ways of knowing (Tester and Irniq 2008; Karetak et al. 2017); it is not terminology we use in our daily life. In this paper we are sharing our own knowledge and experience specific to Pond Inlet. So instead of Inuit Qaujimajatuqangit, we refer to "our knowledge" or "local Inuit knowledge" when we are referring to knowledge held and shared within the community.

For the past 10 years we have been systematically and critically assessing available online environmental services in order to develop, apply, and share our own marine forecasts. Using our knowledge of water and ice conditions around Pond Inlet, we interpret and synthesize online services such as Windy.com, Environment and Climate Change Canada (ECCC) weather and marine forecasts, C-CORE's floe edge monitoring service, Zoom Earth, SmartICE, and Oceans North time-lapse cameras. We then adapt these services to 


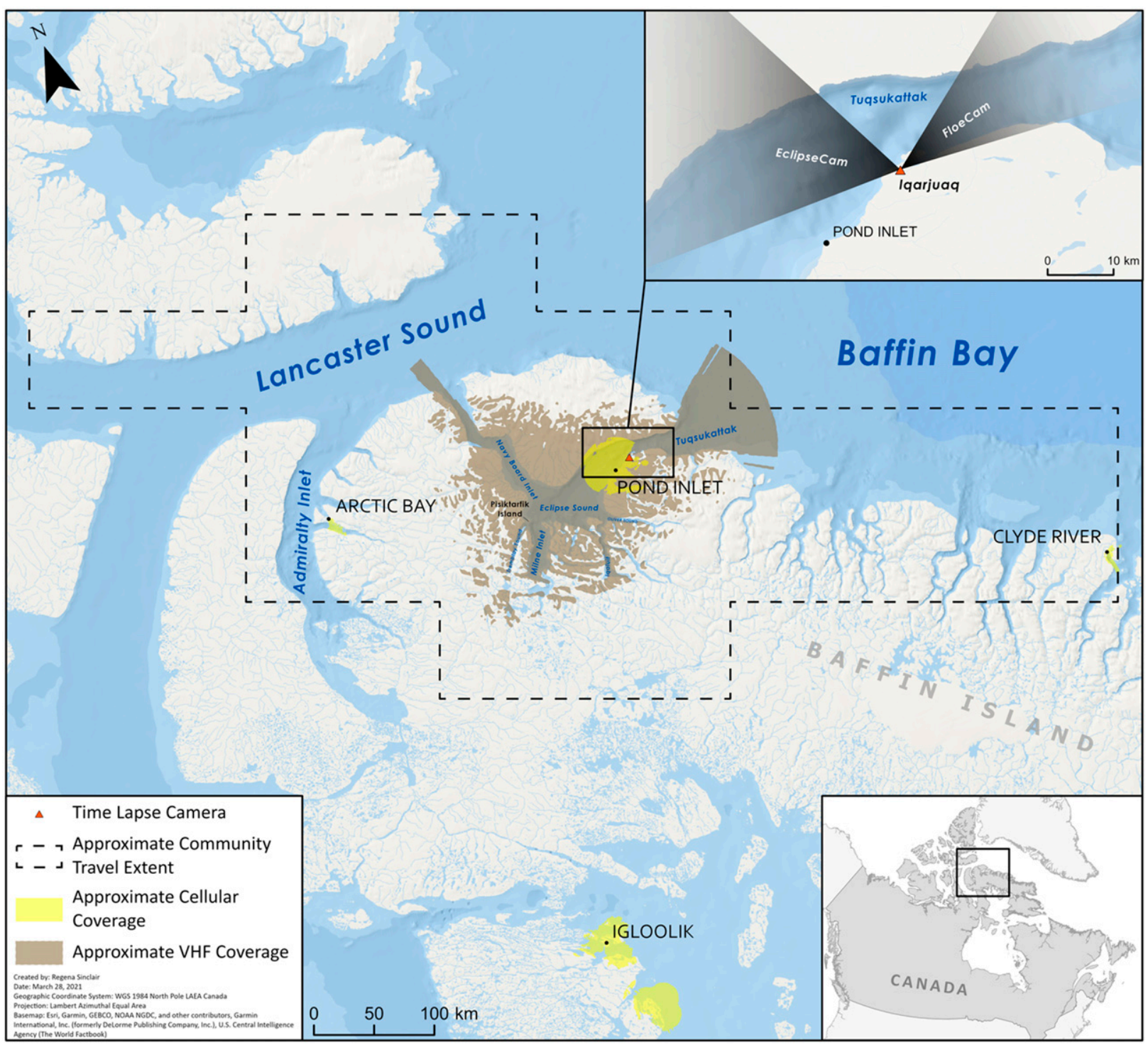

FIG. 1. Location of Pond Inlet, Nunavut, community members' travel area, approximate cellular and VHF marine radio coverage, and Oceans North's time-lapse cameras.

increase their relevance and usefulness for ourselves and our fellow community members in Pond Inlet. In this paper we present the strengths and challenges we have identified in accessing, interpreting, and applying each service throughout different seasons. Our analysis highlights the need for forecasting products and services to be user-friendly, complete, and locally applicable according to cultural and geographic context. If local and regional forecasting is to be improved, there has to be more consideration of relevant environmental indicators, geographic coverage, seasonal coverage, availability, utility, method of communication, language, and accessibility of services for use in Inuit communities.

We began this research long before the recent (much needed) calls for Inuit self-determination in research
(Inuit Tapiriit Kanatami 2018). We are not the only ones doing this kind of work, and we are not the only ones with this knowledge. However, in writing this paper we want to share what we do with a broader audience. As far as we know, this is the first time that such an in-depth, systematic, first-person account of Inuit forecasting efforts has been presented in academic literature. Our research is based on community priorities in Pond Inlet and the application of our long-term (lifelong) systematic observations, analyses, and communications. We want to share our unique community forecasting approach to inform the academic and service provider community of ways that weather, marine, and ice products could be better tailored to the context of Inuit community uses and needs. We also want to share our work to encourage other Inuit in particular, and Indigenous people more broadly, to 
speak and write about their own approaches and findings from a lifetime of environmental interpretation.

\section{Background}

Inuit have made their travel decisions for thousands of years by observing weather, water, and ice conditions, and making forecasts according to season, hunting goals, and known locations (including connections and patterns between places). Some of the most common indicators used in traditional forecasting methods across Inuit Nunangat (Inuit homelands in Canada) are wind direction and strength, tidal cycle, cloud formations, floe edge location, snowfall (especially in fall, on newly formed thin sea ice), blowing snow, animal behavior, areas with strong currents, direction and speed of moving ice, timing of river or sea ice breakup, visibility, wave height, among others (George et al. 2004; Krupnik et al. 2010; Laidler et al. 2011; Gearheard et al. 2013). Inuit made decisions using their own personal knowledge and experience, as well as discussing observations with others. These critical observation skills were passed on from generation to generation as essential for survival and successful hunting and harvesting (Nickels et al. 2005; Pearce et al. 2011; Gearheard et al. 2013; WattCloutier 2015). For travel safety we need to continue practicing these observational and forecasting skills, but not everyone has the experience to do this, and sometimes our traditional indicators are no longer reliable.

In the past, Inuit could predict environmental conditions very accurately; however, climate change is bringing increasingly unpredictable and uncertain weather patterns that make it harder to use local Inuit knowledge to travel safely and hunt successfully (George et al. 2004; Durkalec et al. 2014; Inuit Circumpolar Council 2014; Watt-Cloutier 2015; Panikkar et al. 2018). This also increases the risk we, among other community members, take on while traveling and hunting on the land and sea. Rapidly changing and unpredictable wind, waves, precipitation, storms, and clouds have led to more boating accidents, more incidents of people falling through the ice or being stranded on ice that has broken off, people being stranded out on the land, snow being too hard packed to build an igloo in an emergency, and increased casualties (Gearheard et al. 2010; Durkalec et al. 2014; Inuit Circumpolar Council 2014; Clark et al. 2016; Panikkar et al. 2018). These impacts are compounded when travelers are inexperienced, are inadequately prepared for poor weather, are traveling at high speeds, or when transportation equipment fails, which lead to increased incidents requiring search and rescue (Durkalec et al. 2014; Clark et al. 2016). Although we are adapting with additional preparation and planning before traveling on the land, ice, or ocean, these changes and added risks are also contributing to high rates of food insecurity among Inuit families (Beaumier and Ford 2010; Wesche and Chan 2010; Clark et al. 2016; Inuit Tapiriit Kanatami 2021).

We began to develop, apply, and share our own forecasts with fellow community members for two main reasons. The first reason is out of concern for the impacts of climate and environmental changes described above, especially related to making decisions about travel safety and access to country food (wild food) harvested year-round (e.g., seals) and seasonally (e.g., geese, narwhal, polar bear, fish). In Pond Inlet we have experienced numerous weather-related travel incidents in recent years (Table 1): 67 incidents involving our local search and rescue (SAR) committee occurred between 2015 to 2019 (Government of Nunavut 2016 2017a,b, 2019). We continue to rely on important local weather, ice, ocean, sky, land, and animal indicators that help us to assess travel safety, but we find that these indicators are not as reliable as they used to be. Some of our Elders in Pond Inlet have lost confidence in traditional ways of forecasting and so are more hesitant to share their weather observations and related predictions. They are not alone; similar concerns have been documented across Inuit Nunangat (Nickels et al. 2005; Gearheard et al. 2006, 2010; Weatherhead et al. 2010; Panikkar et al. 2018; Fox et al. 2020).

The second reason we develop, apply, and share our forecasts is that local Inuit knowledge is being shared less often between generations. Similar to other Inuit communities (Furgal and Seguin 2006; Gearheard et al. 2006; Heyes 2011; Pearce et al. 2011; Fawcett et al. 2018; Ford 2019), in Pond Inlet we have seen that fewer inexperienced hunters are seeking to be mentored by experienced hunters and Elders. We notice that inexperienced hunters tend to go out on their own without seeking advice and are making travel decisions based only on conditions they see. They lack sufficient knowledge about wind, sea ice, currents, tides, environmental indicators, and expected or known conditions along their travel route(s) (Nickels et al. 2005; Gearheard et al. 2006, 2010; Panikkar et al. 2018; Ford 2019). In our community we know that inexperienced hunters are very brave, but some of them also take more risks and are not fully prepared for unforeseen events. They may travel in bad weather or dangerous conditions such as high winds and waves, which are risks that more experienced hunters would never take. We have seen inexperienced hunters put themselves and others in danger (e.g., sometimes getting stranded, seeking shelter, and needing help) out of a strong sense of need to get home immediately as a result of homesickness or having run out of cigarettes, sugar, or something of that sort. We encourage inexperienced hunters to seek and apply local Inuit knowledge and available online weather, marine, and ice products when making travel decisions.

It is important to realize how much change has happened between our parents' generation and our own. Simonee was born in 1989, and Alooloo was born in 1948. Over the last 60 years Inuit have gone from living on the land relying on their own knowledge to living in a community with more reliance on modern technologies. This rapid transition was the result of many colonial activities that took place with whaling, traders, policing, federal government activities, residential schools, and more. To put this in perspective, within Alooloo's lifetime we have gone from nomadic to self-governing. And not only have these changes affected our personal and day to day lives, climate change, environmental changes, and technological advances also affect how we live our lives. Inuit are always said to be resilient but, with how fast things have happened, we have to be. Learning how to navigate cultural and environmental changes was not really a choice, it was a matter of life and death. 
TABLE 1. Select examples of weather-related travel incidents around Pond Inlet, Nunavut.

\begin{tabular}{lcc}
\hline \hline Time frame & Weather indicator & Location \\
\hline Regular/ongoing & Wind; waves & \\
& & \\
& & \\
& & \\
June 2007 & Spring thaw (snow turned to slush) & $130 \mathrm{~km}$ from Igloolik toward \\
& & Pond Inlet
\end{tabular}

July $2013 \quad$ Sea ice break off

May 2015

Fog; cold temperature

September 2017 Wind; waves

March $2019 \quad$ Sea ice

February 2021

Whiteout, snowing, and blizzard-like conditions
Navy Board Inlet and Bylot Island

Floe edge

Toward the floe edge area and also near Bylot Island
$450 \mathrm{~km}$ (southwest) from Pond Inlet

SAR was required for hunters stranded because of high winds and high waves; SAR was delayed by high winds but did not stop

Rough ice encountered by two Canadian Rangers led to an accident and a severe injury (punctured lung)

Despite the inclement weather and poor visibility some hunters still left town; a hunter with no means of communicating ran out of fuel; not noticing, the hunter's travel partner left the hunter behind, stranded; on the same day, two young hunters became disoriented when they could not see land; all three hunters were rescued once visibility improved; these incidents would have been averted if weather conditions had been considered prior to travel
Sharing cultural knowledge and experiential lessons learned have been part of our survival as a people.

Somewhere between the rapid environmental changes we are experiencing and the doubts arising around the reliability of traditional forecasting indicators and techniques, we are having to find a balance. Motivated by the challenges outlined above, we began combining our (local Inuit) knowledge with scientific information to assist in decision-making with regard to travel in a changing environment. We are not alone in these efforts. Sikumiut (the Management Committee for SmartICE) in Pond Inlet are also working to combine Inuit Qaujimajatuqangit with community-based 
sea ice monitoring (Wilson et al. 2020, 2021). Community-led initiatives across Inuit Nunangat are also being developed to support travel planning and safety, as well as environmental monitoring and change assessment (Laidler et al. 2011; Kaiser et al. 2019; Segal et al. 2020; Fox et al. 2020). Alaskan Iñupiat and Yupik communities have similarly developed innovative approaches to weather and sea ice forecasts, combining local observations with satellite and instrumental monitoring to support safe travel related to marine mammal hunting activities (Druckenmiller et al. 2009; Eicken et al. 2009, 2014; Lovecraft et al. 2013).

Although environmental indicators of interest and types of land or water travel/use may differ in other parts of the world, our work complements advances being made in combining Indigenous knowledge and scientific information to improve weather and marine forecasting in

- Australia-for extreme weather, shoreline erosion, and storm surges (Green et al. 2010);

- Pacific Island countries-for farming, disaster management, seasonal prediction, tropical cyclones, floods, and drought (Chand et al. 2014; Chambers et al. 2019);

- New Zealand-for aquaculture, fisheries, boating, and volcanic activity (Pardo et al. 2015; Kaiser et al. 2019); and

- sub-Saharan Africa-for drought, agriculture, and extreme weather (Masinde 2015; Barihaihi and Mwanzia 2017).

Collectively, Indigenous peoples are striving to maintain (and revitalize) traditional approaches to weather prediction that support safe travel and subsistence activities in their homelands, tailored to particular cultural beliefs, skills, and practices. Many of the challenges we face in Pond Inlet-and that we are working to overcome-are shared Indigenous experiences where colonization, modernization or other factors have interrupted (intergenerational) knowledge exchange. We also face similar barriers in accessing environmental information relevant to how we travel, hunt, and harvest around our community. Forecasts developed for urban environments or specific economic sectors are not relevant to seasonal activities around Pond Inlet, so we have to work harder to access and interpret information we need.

\section{Our community and our research approach}

\section{a. Our community}

Our coastal hamlet of Pond Inlet is located on the shore of Eclipse Sound, east of Navy Board and Milne Inlets, on northern Baffin Island (Fig. 1). Our community has a population of 1617 , and $93 \%$ of community members identify as Inuk (Inuit is plural) (Statistics Canada 2016). For 4000 years, the area around Pond Inlet has been occupied, and people have hunted on the sea, ice, and land throughout the periods archaeologists refer to as pre-Dorset, Dorset, Thule, and modern Inuit (Qikiqtani Inuit Association 2013). Community members harvest numerous naturally available resources year-round for domestic consumption and for clothing, as well as to share, trade, and sell within and beyond the community (Carter et al. 2018; Gilbert et al. 2021). Seals are at the heart of our local
Inuit culture and are critical to community food security, health, well-being, and livelihoods. However, harvesting, sharing, and consuming other marine and terrestrial animals, eggs, and plant products are also of vital importance (Gilbert et al. 2021). Elders, hunters, families, and guides access the land and marine areas year-round to hunt, camp, and travel. Many community members travel extensively (upward of a $400-\mathrm{km}$ radius from the hamlet) (Fig. 1) by boat, all-terrain vehicle, snowmobile, and passenger vehicle (e.g., pick-up truck) depending on seasonal conditions (Carter et al. 2018). There are no roads connecting Nunavut communities, so travel between communities is only over land, water, ice, or by commercial airline (Government of Nunavut 2012).

\section{b. Our coauthorship approach}

Throughout this paper, "we" and "our" reflects N. Simonee and J. Alooloo's lifelong observations, research initiatives, and forecasting approaches in Pond Inlet. This is the first time we have tried to write about our work in order to share our efforts and findings outside our community. We reached out to involve our coauthors (N. Carter, G. Ljubicic, and J. Dawson) on the basis of relationships we had developed working together in previous projects, and ongoing connections and shared interests. Our coauthors gave us input and support in contextualizing our research within current literature and in presenting this work to reach a broader audience. However, the research and analysis are our own.

\section{c. Our observations}

We have gained our local Inuit knowledge through our own observations and also through guided mentorship that is common in our culture. We have both traveled extensively around Pond Inlet our whole lives. This lifelong learning totals $100+$ years of combined experience. Through ongoing use of lands, waters, and ice around our community we are always observing, and have become increasingly in tune with the important messages we can hear, feel, and see in our environment. These messages help us to make decisions about safe travel and hunting. Through our experiences we have acquired an extensive knowledge base of environmental signs (indicators) that we observe, assess, synthesize, and apply when predicting weather, marine, and ice conditions, including, for example, clouds, sky, mirages, sound, weather in other communities, and animal behavior (Table 2; Fig. 2). Taken together these indicators help us to develop a comprehensive knowledge base of local conditions, patterns, and risk factors that inform our weather and ice forecasts at different times of year.

We draw on our experiences, knowledge, and key indicators described above as the foundation of our assessments of travel safety. However, when developing our community forecasts, we also consider, evaluate, and integrate a specific selection of information including 1) number of daylight hours; 2) travel purpose, destination, and duration; 3) travel surface (e.g., frozen or open ocean/rivers/lakes, floe edge, inland, highlands/hills); 4) common weather conditions (seasonally and geographically); and 5) expected risks, extreme weather events, and particular dangers (Table 3). For example, 
TABLE 2. Select examples of environmental indicators used to assess travel safety around Pond Inlet, from the point of view of the first two authors.

\begin{tabular}{ll}
\hline \hline \multicolumn{1}{c}{ Indicator } & Description/application \\
\hline Clouds & If we see big, thick, fluffy, dark clouds in the direction of Arctic Bay (a hamlet about 200 km west of \\
Pond Inlet) we expect bad weather or rain in Pond Inlet \\
If we see layered clouds (three layers or thin streaks of clouds) we expect wind in Pond Inlet \\
If it looks like there is a line of smoke (formed by clouds) at Bylot Island, then we know that it is windy \\
between Pond Inlet and Bylot Island (Fig. 2a) \\
Clouds \\
We call a nearby mountain Igarjuaq (Mount Herodier), meaning "huge oven," because when clouds \\
build up behind the mountain it looks like smoke coming out of an oven; when Igarjuaq has \\
smokelike cloud or fog above it and resembles chimney (Fig. 2b), or when clouds cover its peak or \\
either side (Fig. 2c), then we expect a few windy days \\
When we see the sky begin to open up toward Emerson Island, after days of dark skies and bad weather \\
(gray; snowing), we know that good weather is on its way \\
When Bylot Island appears to be much closer to Pond Inlet than usual, and we can see it very clearly, \\
then we know that it is windy at Bylot Island or windy between Pond Inlet and Bylot Island \\
When we hear snowmobiles from farther away than normal, we know it will become windy (because \\
the wind allows sound to travel much farther than usual) \\
Mirage \\
Igloolik is a hamlet about 400 km southwest of Pond Inlet (Fig. 1); we know that whatever weather \\
Igloolik has, we can expect similar weather in our community within 3 days \\
When rabbit, ptarmigan, and seals are not in their usual locations, we know that wind is on its way \\
(animals sense the wind coming much sooner than humans) \\
Wheather in other communities \\
Animal behavior
\end{tabular}

in March and April, with 12-18 h of daylight, our trips range from a few hours to a week. At that time of year, we tend to travel on sea ice, access open water (at the floe edge), and travel overland including on frozen lakes and rivers. In March and April, we are mostly concerned with dangers related to thin ice at the floe edge, and weather conditions that cause near-zero or zero visibility (e.g., blizzard, blowing snow, and mist/fog) (Table 3). In June, with $24 \mathrm{~h}$ daylight, our trips range from day trips to weeks if we are at the floe edge, or up to 3 months if on the land (i.e., we do not come back to the community until it is boating time). At that time of year, we are still traveling on sea ice, but also crossing over leads, using open water, and over land watching out for melting or open lakes and rivers. Therefore, particular risks we consider include crossing wide leads, thin ice at the floe edge, fog, rain causing puddles and increased snowmelt, slush in melting
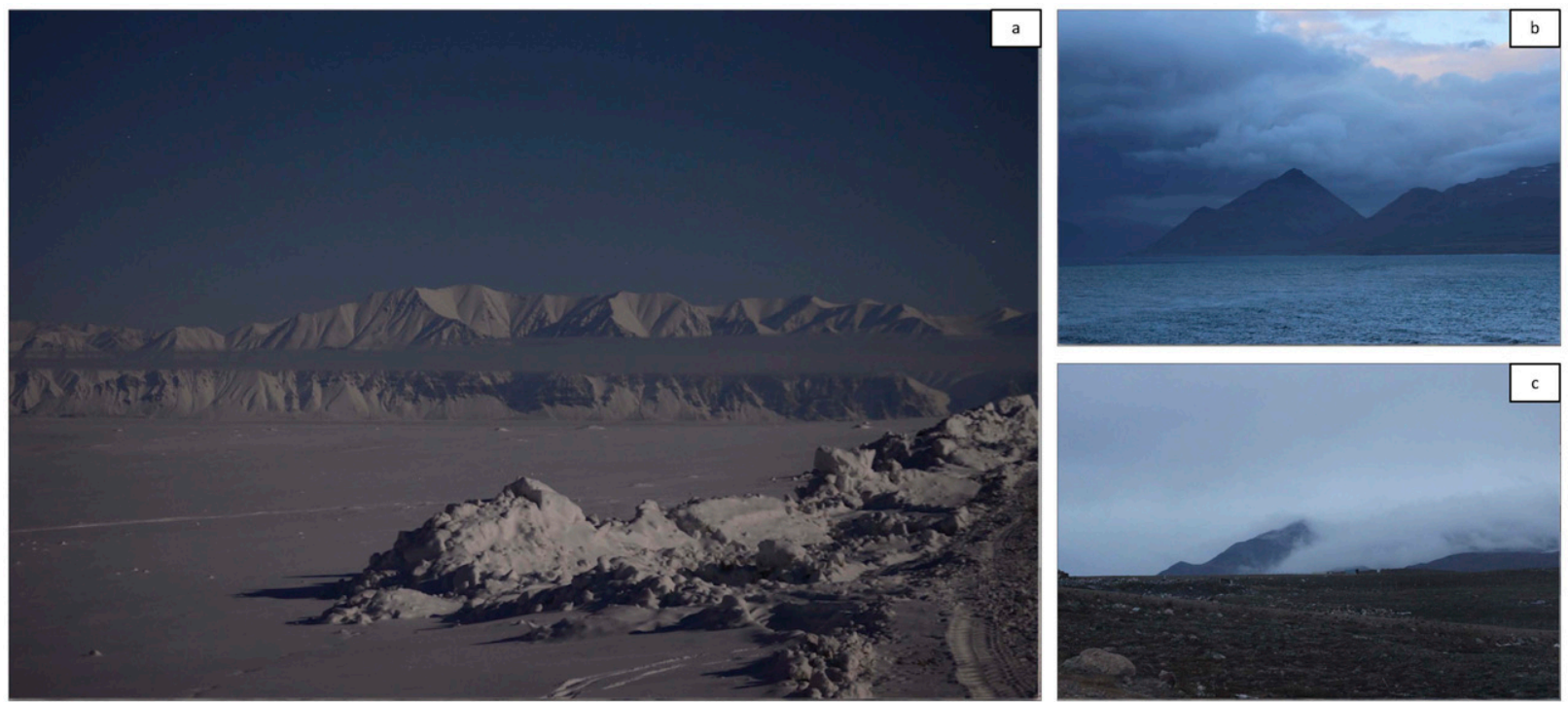

FIG. 2. Examples of signs (indicators) that are observed and used to make travel decisions. (a) When there is a line of smoke (formed by clouds) at Bylot Island, then we know that it is windy in between Pond Inlet and Bylot Island. (b) When Igarjuaq (Mount Herodier) resembles a chimney with smokelike clouds or fog above it, then we expect a few windy days. (c) When clouds cover the peak or either side of Igarjuaq (Mount Herodier), then we expect a few windy days. 
TABLE 3. Local weather conditions and known risks considered when assessing safe travel throughout the year around Pond Inlet. With Garmin inReach satellite technology we send and receive messages; navigate, track, and share our route; and trigger an "SOS" message to get help, if necessary.

\begin{tabular}{|c|c|c|}
\hline $\begin{array}{c}\text { Travel purpose, destination; duration (travel } \\
\text { surface) }\end{array}$ & Common weather conditions & $\begin{array}{c}\text { Risks, extreme weather events-Particular } \\
\text { dangers }\end{array}$ \\
\hline \multicolumn{3}{|c|}{ March and April (12-18h of daylight) } \\
\hline $\begin{array}{l}\text { Fetching ice from icebergs for drinking water/tea; } \\
\text { a few hours (sea ice) }\end{array}$ & $\begin{array}{l}\text { Potentially really cold even if } \\
\text { warmer during the day }\end{array}$ & $\begin{array}{l}\text { Dangerously thin fresh ice in floe edge } \\
\text { area-High risk of being stranded on broken } \\
\text { off ice or falling through thin ice }\end{array}$ \\
\hline $\begin{array}{l}\text { Hunting seals, seal pups, and narwhal at floe edge } \\
\text { and seals at breathing holes in sea ice; day trip } \\
\text { or overnight (sea ice; open water) }\end{array}$ & Longer daylight & $\begin{array}{l}\text { Blizzard: blowing snow and/or mist/fog causing } \\
\text { near-zero or zero visibility-Risk of } \\
\text { unexpectedly encountering a drop-off/ditch/ } \\
\text { unfrozen river/rough ice and not being able to } \\
\text { turn or stop in time to avoid an incident }\end{array}$ \\
\hline
\end{tabular}

Fishing in lakes; $3-5$ days (sea ice, land, frozen Getting warmer rivers, and lakes)

Hunting caribou, ptarmigan, and Arctic hares; 3 Blowing snow and wind days +2 nights, or up to a week (sea ice, inland and upland, frozen rivers)

Blizzards (infrequent)

Deep snow, whiteout, misty/foggy

April: less windy than March

May (24 h of daylight)

Hunting narwhal at floe edge; from day trip to up to a week (sea ice; open water)

Hunting seals at floe edge, breathing holes, and when they are on top of the ice sunning themselves; day trip to up to a week (sea ice, open water, leads)

Hunting geese and ducks; day trip (sea ice, frozen or open rivers, valleys, and land/tundra)

Hunting narwhal and walrus; hunting bearded seals and ringed seals at floe edge, breathing holes, or leads; from day trip to weeks if at floe edge, or months if not at floe edge (sea ice, leads, and open water)

Hunting geese and eider ducks, picking goose, eider duck, Arctic tern, and gull eggs; day trip from another camp, e.g., combine it with seal hunting, or up to a week (sea ice; land around melting/melted lakes)

Fishing in sea ice; day trip from another camp (sea ice; leads)

Picking murre eggs; day trip from another camp (sea ice, open water, cliffs, and melting rivers)
June (24h of daylight)

Foggy; rain; snow does not blow around as much as in March-May
Dangerously thin fresh ice in floe edge area-High risk of being stranded on broken off ice or falling through thin ice

Crossing snow-covered open water (melting tidal cracks)-The snowmobile may slowly sink or hit a bump on the climb out the other side, causing it to stop abruptly or flip, then the qamutik (sled) may hit the snowmobile; all causing the snowmobile and driver to fall into open water

Whiteouts (flat light); i.e., sky and ground all one color and cannot see to where traveling-Sudden arrival at rough ice, ditch, or leads with insufficient time to stop or turn

Crossing wide leads-Sudden arrival at leads with insufficient time to stop or turn

Dangerously thin fresh ice in floe edge area-High risk of being stranded on broken off ice or falling through thin ice

Fog resulting in reduced visibility-Sudden arrival at leads with insufficient time to stop or turn

Rain causes puddles on sea ice to get deeper and speeds up snowmelt on the ice; where river flow meets sea ice, large pools of open water form (aktinniit)-Risk of puddles too deep to cross so snowmobile breaks down and therefore must drag snowmobile from the water by hand 
TABLE 3. (Continued)

\begin{tabular}{ccc}
\hline $\begin{array}{c}\text { Travel purpose, destination; duration (travel } \\
\text { surface) }\end{array}$ & Common weather conditions & $\begin{array}{c}\text { Risks, extreme weather events-Particular } \\
\text { dangers }\end{array}$ \\
\hline
\end{tabular}

Typical time on the land in June is day trip, 2 weeks, or even 3 months and not coming back to town until boating time

Slush forming in melting rivers; where river flow meets sea ice, large pools of open water form (aktinniit)-Risk of getting stuck in slush

Fatigue and sleep deprivation from spending up to $30 \mathrm{~h}$ on the ice without sleep-Risk of falling asleep when driving and/or sudden arrival at leads with slower reflexes and/or insufficient time to stop or turn

Sun and glare-Risk of sunburn; reflection/glare of the sun is blinding so need to be careful where one drives in relation to the sun's position because large holes or leads may not be seen

Hunting narwhal; from overnight to a week

July (24h of daylight)

(open water, leads, sea ice, and thinning holes in ice)

Picking murre eggs; day trip during floe edge hunting (sea ice, open water, cliffs, and melting rivers)

Hunting bearded seals and ringed seals at floe edge, breathing holes, or leads; from day trip to weeks if at floe edge, or for months if not at floe edge (sea ice, leads, and open water)

Fishing in sea ice and open water from shore; day Nice; hot trip from another camp (sea ice; leads)

Foggy; rain

By far has the nicest weather as far as not much change

Not fluctuating; mostly consistent all month long tip from anther camp (sea ice; leads)

Hunting seals using small boats; from $2 \mathrm{~h}$ to a day Everything is melting trip (areas of open water because still mainly ice)

Usually has wind

August (18h of daylight)

Hunting bearded seals, ringed seals, and walrus; Foggy; raining day trip or happens at camp (open water and seals can be on ice floes)

Hunting narwhal; day trip or 1-2 weeks

(open water)
Fog resulting in near-zero to zero visibility-Sudden arrival at leads with insufficient time to stop or turn

Cliff climbing to pick murre eggs-Wet conditions make rocks slippery and dangerous

Crossing wide leads-If edges are thin, it can make crossing difficult; the thin edges could break

Ice is no longer safe to travel on-The sea ice is breaking in many directions and is no longer land fast (ilinngaaniq), and leads are perpendicular to the land

During second puddling the ice is becoming unsafe-(holes forming in the ice) so one stays off the ice

Sea ice detaches from the land and becomes floating ice that moves with tides and currents-When the puddling on top of this ice evaporates, it is a sign that the ice is not going to last much longer

Sun risk- Risk of sunburn; reflection/glare of the sun is blinding so need to be careful where one drives in relation to the sun's position because large holes or leads may not be seen

Strongest river flows-Melting areas from river flow are much bigger and more dangerous: even higher risk than June

Floe edge and ice floes are a danger

Fog resulting in near-zero to zero visibility - Sudden realization that one is very close to other boaters, large animals, or icebergs and does not have time to turn to avoid them

River flow can be strong from increased rain-Risks include poor-quality drinking water, difficulty crossing, and being brought adrift by flow/current 
TABLE 3. (Continued)

\begin{tabular}{|c|c|c|}
\hline $\begin{array}{c}\text { Travel purpose, destination; duration (travel } \\
\text { surface) }\end{array}$ & Common weather conditions & $\begin{array}{c}\text { Risks, extreme weather events-Particular } \\
\text { dangers }\end{array}$ \\
\hline $\begin{array}{l}\text { Hunting caribou and geese by boat, all-terrain } \\
\text { vehicle (ATV), or on foot; when narwhal } \\
\text { hunting or from another camp (open } \\
\text { water; land) }\end{array}$ & & $\begin{array}{l}\text { Risk of boat capsizing from waves and rough } \\
\text { water or pieces of ice in the sea }\end{array}$ \\
\hline \multicolumn{3}{|l|}{$\begin{array}{l}\text { Picking berries by car, boat, ATV, or on foot; } 2 \text { h, } \\
\text { daytrip, or a few days-can happen during } \\
\text { caribou hunting }\end{array}$} \\
\hline \multicolumn{3}{|l|}{$\begin{array}{l}\text { Fishing in sea and lakes; day trip (open water; } \\
\text { land by ATV) }\end{array}$} \\
\hline \multicolumn{3}{|c|}{ September (12 h of daylight) and October (7 h of daylight) } \\
\hline $\begin{array}{l}\text { Hunting ringed, bearded, and harp seals; day trip } \\
\text { (open water in September; ice forming in } \\
\text { October) }\end{array}$ & Multiyear ice starts to come in & $\begin{array}{l}\text { Risk of boat capsizing from strong winds, high } \\
\text { waves, and swells }\end{array}$ \\
\hline Picking berries; day trip (land) & Snow & $\begin{array}{l}\text { October: sea ice is forming. Ice is too thick for } \\
\text { boating, and too thin for snowmobiles }\end{array}$ \\
\hline Hunting narwhal; day trip (open water) & $\begin{array}{l}\text { Rivers start to freeze so flow is not } \\
\text { as strong } \\
\text { Winds are much stronger than in } \\
\text { August (fewer calm-water days) } \\
\text { Shorter periods between windy } \\
\text { and rough-water days } \\
\text { October: beach starts to get icy; sea } \\
\text { ice is forming }\end{array}$ & \\
\hline $\begin{array}{l}\text { Hunting seals; day trip (fresh sea ice in limited } \\
\text { areas near Pond Inlet) }\end{array}$ & $\begin{array}{l}\text { November (0h of daylight) } \\
\text { Beach starts to get icy }\end{array}$ & $\begin{array}{l}\text { Thin sea ice-ice is too thick for boating and too } \\
\text { thin for snowmobiles }\end{array}$ \\
\hline $\begin{array}{l}\text { Hunting seals in tidal cracks; day trip (fresh } \\
\text { sea ice) }\end{array}$ & & $\begin{array}{l}\text { Risk of falling through snow-covered thin ice, } \\
\text { slush, or water }\end{array}$ \\
\hline $\begin{array}{l}\text { Hunting caribou; from } 3 \text { days to a week (frozen } \\
\text { lakes, rivers, land) }\end{array}$ & & $\begin{array}{l}\text { Icy beach-Makes it hard to pull in boats and is } \\
\text { slippery (risk of falling) }\end{array}$ \\
\hline & & $\begin{array}{l}\text { Losing one's hunting partner while hunting in } \\
\text { the dark }\end{array}$ \\
\hline \multicolumn{3}{|c|}{ December ( 0 h of daylight), January ( $0 h$ of daylight), and February $(7 \mathrm{~h}$ of daylight) } \\
\hline $\begin{array}{l}\text { Hunting seals at breathing holes; day trip } \\
\text { (sea ice) }\end{array}$ & Dark; cold & Thin ice outside Pond Inlet area \\
\hline $\begin{array}{l}\text { Fishing and hunting caribou; from } 3 \text { days to a } \\
\text { week (frozen lakes, rivers, land, and sea ice) }\end{array}$ & Blowing snow & $\begin{array}{l}\text { Risk of falling, rolling snowmobile, and/or } \\
\text { qamutik when climbing hills, driving in valleys, } \\
\text { and following caribou on rocky terrain } \\
\text { Losing one's hunting partner while hunting in } \\
\text { the dark }\end{array}$ \\
\hline
\end{tabular}

rivers, river flow causing increased sea ice melt, driving when tired, and risk of sunburn or snow blindness (Table 3). As you can see from just these two examples, our travel crosses almost every type of surface over short and long durations, and the associated safety factors we consider vary extensively within and between months and for each destination. Table 3 is not exhaustive; rather, it highlights key aspects of our experience and the most common observations that we integrate into our local forecasts.

\section{d. Combining our knowledge with online products}

We have been using and assessing online weather, marine, and ice products for the past decade (a combined 20 years). Since 2015, we have been communicating our forecasts to fellow community members as a public service, and to individuals upon request. We do this independently, free of charge, on our own time, with no set schedule. We provide our forecasts over multiple very high frequency $(\mathrm{VHF})^{1}$ marine radio channels, as well as on local radio and Facebook. Our goal is to provide information to local hunters, and others who go out on the land and sea, in order to reduce risk and enable informed decisionmaking for safe travel. Over this time, we have been refining

\footnotetext{
${ }^{1}$ VHF marine radio is a global system of two-way radio transceivers on ships and marine craft used for two-directional voice communication from vessel to vessel, vessel to shore, and sometimes vessel to aircraft.
} 
TABLE 4. Weather, marine, and ice information sources consulted when developing community weather forecasts for the purposes and destinations around Pond Inlet that are outlined in Table 3.

\begin{tabular}{|c|c|c|c|}
\hline Information source & Month(s) & Relevant information & Website \\
\hline $\begin{array}{l}\text { Word of mouth via FM radio, } \\
\text { VHF marine radio, discussions } \\
\text { at coffee shop, and Facebook }\end{array}$ & June-August & $\begin{array}{l}\text { Observations and updates by } \\
\text { many people traveling on the } \\
\text { land, ice, and water }\end{array}$ & - \\
\hline $\begin{array}{l}\text { Word of mouth with people met } \\
\text { en route on the land or ice }\end{array}$ & November-February & $\begin{array}{l}\text { Observations of travel } \\
\text { conditions, and safe travel } \\
\text { routes }\end{array}$ & - \\
\hline Windy.com & June-November & $\begin{array}{l}\text { Wind speed and direction for the } \\
\text { next } 7 \text { days }\end{array}$ & https://www.windy.com \\
\hline ECCC weather forecast & Year-round & $\begin{array}{l}\text { General weather (wind, sun, } \\
\text { or cloud) }\end{array}$ & $\begin{array}{l}\text { https://weather.gc.ca/city/pages/ } \\
\text { nu-25_metric_e.html }\end{array}$ \\
\hline $\begin{array}{l}\text { Fisheries and Oceans Canada } \\
\text { tides, currents, and water } \\
\text { levels }\end{array}$ & June-August & $\begin{array}{l}\text { Predicted hourly heights for } \\
\text { Pisiktarfik Island and } \\
\text { Milne Inlet }\end{array}$ & $\begin{array}{l}\text { https://www.waterlevels.gc.ca/ } \\
\text { eng/find/zone/39 }\end{array}$ \\
\hline ECCC marine forecast & $\begin{array}{l}\text { No longer used; used to be used } \\
\text { in July-September but now } \\
\text { only use Windy.com }\end{array}$ & Winds; extended forecast & $\begin{array}{l}\text { https://weather.gc.ca/marine/ } \\
\text { index_e.html }\end{array}$ \\
\hline $\begin{array}{l}\text { Polar View C-CORE floe edge } \\
\text { monitoring service }\end{array}$ & March-August & $\begin{array}{l}\text { (Changes in) floe edge location; } \\
\text { open water, areas of ice } \\
\text { concentration, multiyear ice, } \\
\text { and break up of ice; pieces } \\
\text { of ice }\end{array}$ & http://www.ccore.ca/floeedge/ \\
\hline Zoom Earth & March-August & $\begin{array}{l}\text { (Changes in) floe edge location; } \\
\text { open water, areas of ice } \\
\text { concentration, multiyear ice, } \\
\text { and break up of ice; pieces of } \\
\text { ice; ice leads }\end{array}$ & https://zoom.earth \\
\hline SmartICE & December-May & $\begin{array}{l}\text { Sea ice thickness and roughness } \\
\text { (recorded using a "smart } \\
\text { qamutik"; i.e., a mobile sensor } \\
\text { riding on a sled pulled behind a } \\
\text { snowmobile) }\end{array}$ & https://siku.org \\
\hline $\begin{array}{l}\text { Oceans North floe edge cam and } \\
\text { eclipse cam }\end{array}$ & $\begin{array}{l}\text { No longer used because it is not } \\
\text { operational; used to be July } \\
\text { (when floe edge is within range } \\
\text { of cameras) }\end{array}$ & $\begin{array}{l}\text { Floe edge location (and changes } \\
\text { in location) }\end{array}$ & $\begin{array}{l}\text { https://oceansnorth.org/en/ } \\
\text { monitoring-sea-ice-in- } \\
\text { Tasiujaq/\#clearday }\end{array}$ \\
\hline
\end{tabular}

our forecasts by considering what information to include and how best to communicate.

When planning hunting trips and developing forecasts to support safe travel, we often consult with Elders and other knowledgeable community members, sharing observations and updates by word of mouth in person, over community radio, VHF radio, satellite phone, social media, and so on (Table 4). Word of mouth is really important in understanding common travel risks during the current season or in specific locations, as well as weather patterns and conditions to consider for safe travel. We then combine this collective community knowledge with online weather, marine, and ice products. To do this we consult numerous online products (Table 4), depending on the month, travel route, and destination. Most commonly, we check Windy.com (Figs. 3a-d), ECCC marine forecast, ECCC weather forecast (Fig. 3e), Department of Fisheries and Oceans tide tables (Fig. 3f), Polar View C-CORE floe edge monitoring service (we call it Polar View in the community; Fig. 4a), Zoom Earth (Fig. 4b), and SmartICE. (Fig. 4c). We do this using our home computers and cellular telephones ("cell phones").

\section{e. Our evaluation and use of environmental information from online products}

Over the past decade, we have evaluated the relevance of available online products in terms of their potential for local application. We have assessed the strengths and challenges of each product, according to several key factors: ease of understanding, interpreting, and applying products for forecasting and real-world travel situations; extent and resolution of geographic and temporal coverage; language and presentation (i.e., jargon, technical terms, units of measurement, icons, and text summaries); and accessibility (i.e., image/graphic size/resolution/type for download or streaming given local bandwidth and internet access limitations). We have also iteratively refined our approach to communicating forecasts by reflecting on our methods, and through feedback from those who use our forecasts. We have assessed many audience-related factors, including the degree of local Inuit knowledge held by community 

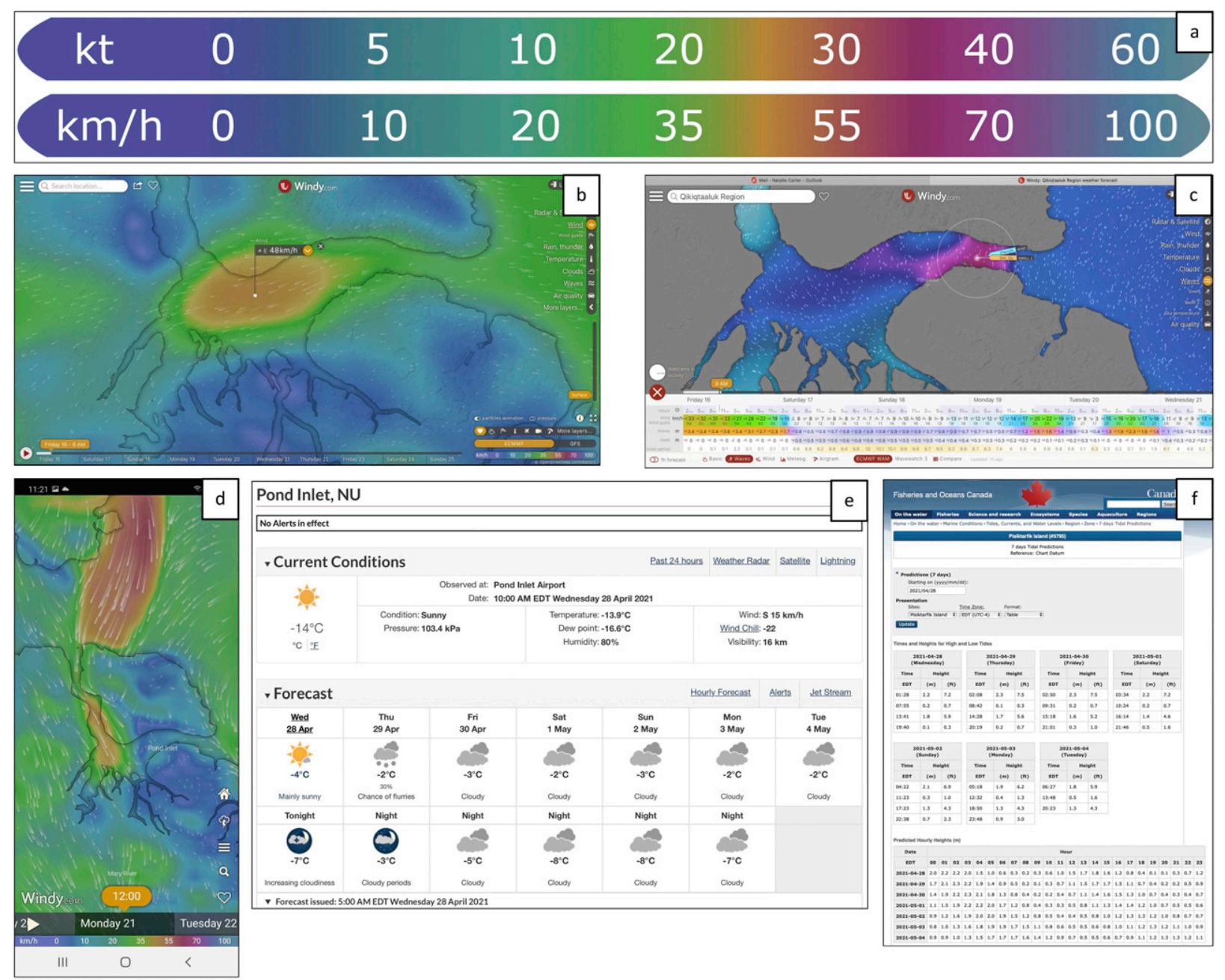

FIG. 3. (a) Windy.com color-coded wind speed gradient and examples of wind, weather, and tide forecast products consulted when developing forecasts to support decision-making for safe travel around Pond Inlet, Nunavut. (b),(c) Windy.com wind forecasts on computer screen. (d) Windy.com wind forecast in mobile application. (e) Environment and Climate Change Canada weather forecast. (f) Fisheries and Oceans Canada tidal predictions.

members (place names, wind directions, and currents); dialectal differences (place names; specialized Inuktitut terminology); and other information community members may have acquired through popular and/or social media. We have also assessed factors related to how and where we share forecasts (e.g., radio and Facebook) to understand impact. The results of our assessments are detailed in the following sections, in terms of how we tailor our forecasts to meet community needs.

\section{Tailoring our forecasts to meet community needs}

The way we evaluate and use community observations along with online environmental products varies by time of year and purpose of travel (Tables 3, 4). Weather and marine information is most crucial for us in Pond Inlet during boating season. It is less significant to have this information in other seasons because if it is windy in the winter, we can still drive a snowmobile, but in the summer, wind is the deciding factor to determine travel safety. The process of how we combine our own knowledge with all available information shared by word of mouth and environmental forecasting products involves many steps and is hard to explain in writing. However, in this section we use the example of how we evaluate Windy.com services to demonstrate how we assess weather, marine, and ice products. We also outline our forecasting process during boating season that informs our travel decision-making. Last, we explain some key considerations in communicating our local forecasts.

\section{a. Evaluating Windy.com for boating conditions}

Despite the importance of wind in determining safe travel in the summer (boat safety) and winter (visibility) [see review in Gearheard et al. (2010); also Fox et al. (2020)], the reliability of wind observations and forecasts across products is low because of a lack of observing sites in the Arctic (Johnson et al. 2015; 


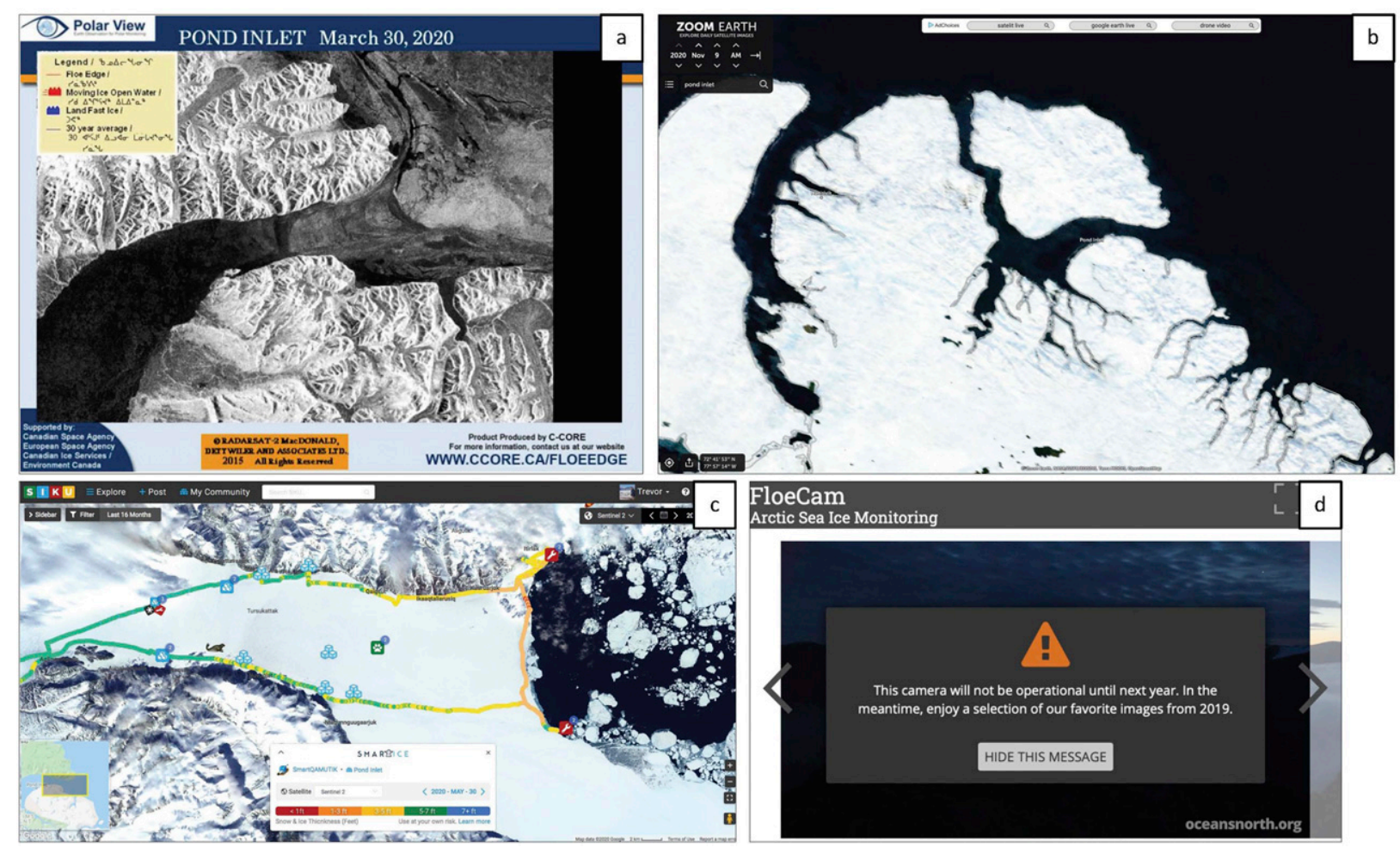

FIG. 4. Examples of ice condition products consulted when developing forecasts to support safe travel decision-making around Pond Inlet, Nunavut. (a) Polar View C-Core floe edge monitoring service sea ice conditions imagery. (b) Zoom Earth sea ice conditions imagery. (c) SmartICE snow and ice thickness information. (d) Oceans North Floe Cam (camera not operational). Image sources: see Table 4 for website URLs.

WMO 2017). So, when Windy.com became available in 2014 it was of immediate interest to us. However, at first wind speed was only provided in knots $\left(\mathrm{kt} ; 1 \mathrm{kt} \approx 0.51 \mathrm{~m} \mathrm{~s}^{-1}\right)$, a unit of measurement with which we were unfamiliar and unable to relate to real-world conditions. Wind speed was provided numerically and through color-coded graphics in which specific colors and shades corresponded to ranges of wind speed (Fig. 3a).

To relate wind speeds to boating conditions, we asked hunters for feedback while they were boating. For instance, if Windy.com was showing shades of green (i.e., wind conditions around $19 \mathrm{kt}$, which we converted to $35 \mathrm{~km} \mathrm{~h}^{-1}$ ), we asked hunters for their exact location, then clicked on that location on Windy.com. The wind speed and direction for their specific location would pop up in a little flag (i.e., showing the current modeled conditions). We asked, "What is the weather like there? What are you seeing exactly? Would you travel in that safely?" One time a hunter answered, saying, "Yes, I would travel in an emergency, but I wouldn't travel if I was just homesick." By doing this repeatedly over two summers, we learned how Windy.com information aligned with travel conditions, how to mentally convert knots to kilometers per hour, and how to interpret the color-coded wind speed gradient to know when we can and cannot travel.

Today Windy.com provides the option to view wind speed in kilometers per hour. We love seeing the lilac and blue colors $\left(0-20 \mathrm{~km} \mathrm{~h}^{-1}\right)$; it means it is very calm. If it is green $\left(21-35 \mathrm{~km} \mathrm{~h}^{-1}\right)$, we would rather not travel, but we could if we had to (Figs. 3b,c). We would never travel if we see colors from orange to purple $\left(36-55 \mathrm{~km} \mathrm{~h}^{-1}\right.$; Figs. $\left.3 \mathrm{c}, \mathrm{d}\right)$ or red $\left(>56 \mathrm{~km} \mathrm{~h}^{-1}\right)$. Windy.com has become our main wind information source. We do not need to look at the wave information that Windy.com also provides, because we can now envision the water conditions in our area based on the wind speed and direction. Originally, we used computers but now we often use the mobile application (app) to access Windy.com.

\section{b. Forecasting during boating season}

Figures 5 and 6 represent our forecasting process during boating season that informs our decision-making about whether it is safe to travel. We also share these forecasts with other community members in Pond Inlet to help them make their own assessments. We go through a few different steps when we are planning to leave from the community, or when we are already out on the land and planning to return home.

When planning to leave Pond Inlet to reach one of our camps where we can hunt; fish; gather plants, water, or eggs; or just spend time on the land as a family, we first check the 7-day forecasts using Windy.com and ECCC Weather (Fig. 5). When reviewing the Windy.com wind models we zoom in to specific areas of interest, looking at the 7-day timeline and assessing 


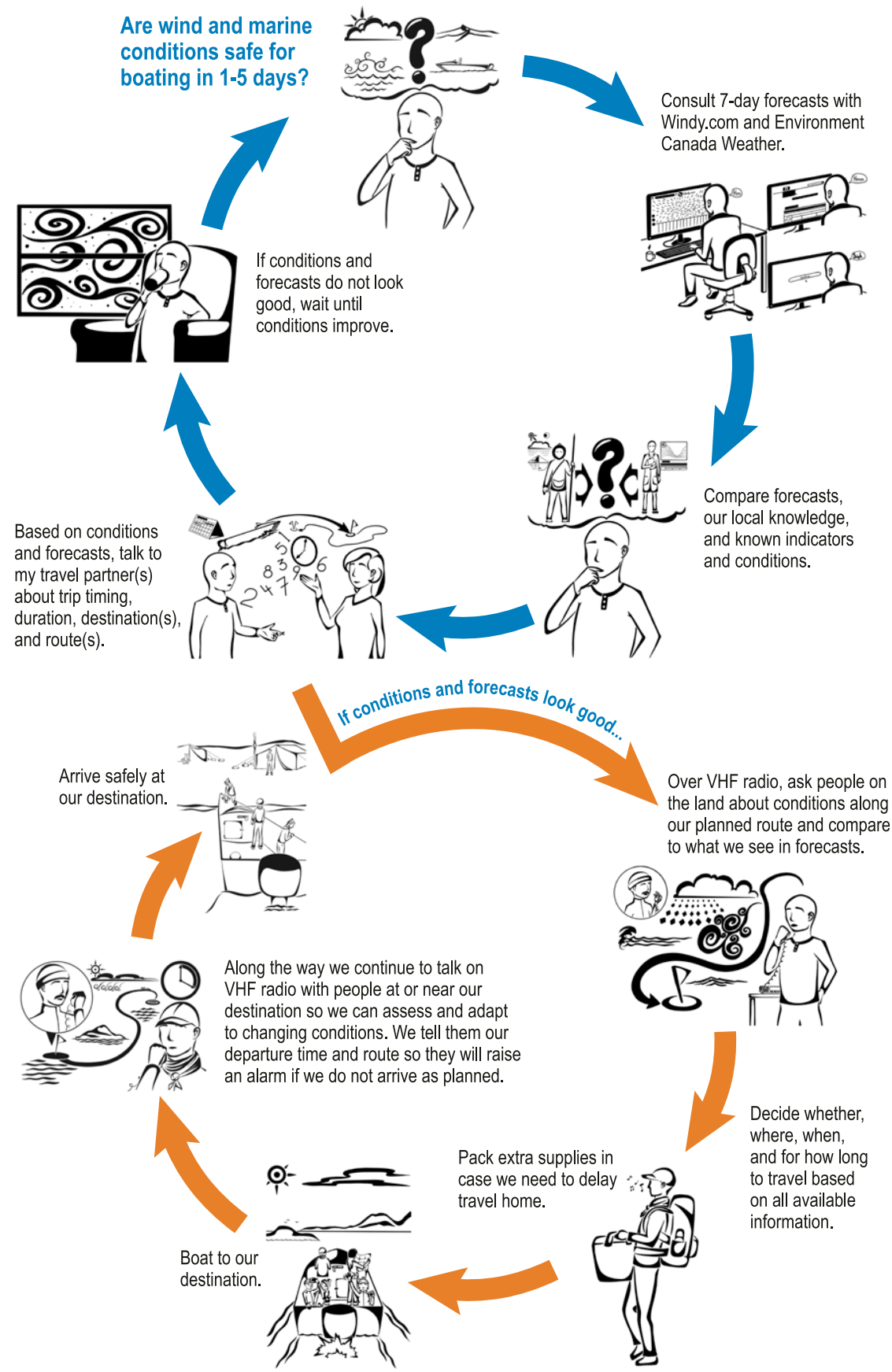

FIG. 5. Forecasting process to decide whether it is safe to travel out of the community by boat (illustrations by J. Itulu).

colors that translate to known travel conditions (Figs. 3a-d). We then compare these with the general ECCC weather forecasts (Fig. 3e), as well as with our understanding of known indicators and conditions. We discuss these conditions with our travel partner(s), and, if forecasts do not look good, we wait in town until conditions improve (Fig. 5). If conditions seem good, then we call people who are already out near the area where we plan to travel (Fig. 5). We ask them about local conditions, and we compare what they say with what we have seen in forecasts. The observations of people we contact on the land carry more weight in our decisions than the environmental information we check online, because people can assess the actual conditions in the area. If no one is at our intended destination, we have to make our own judgements. In that case we work with available information, but then we are also more cautious and may wait until we are more certain. We take all 


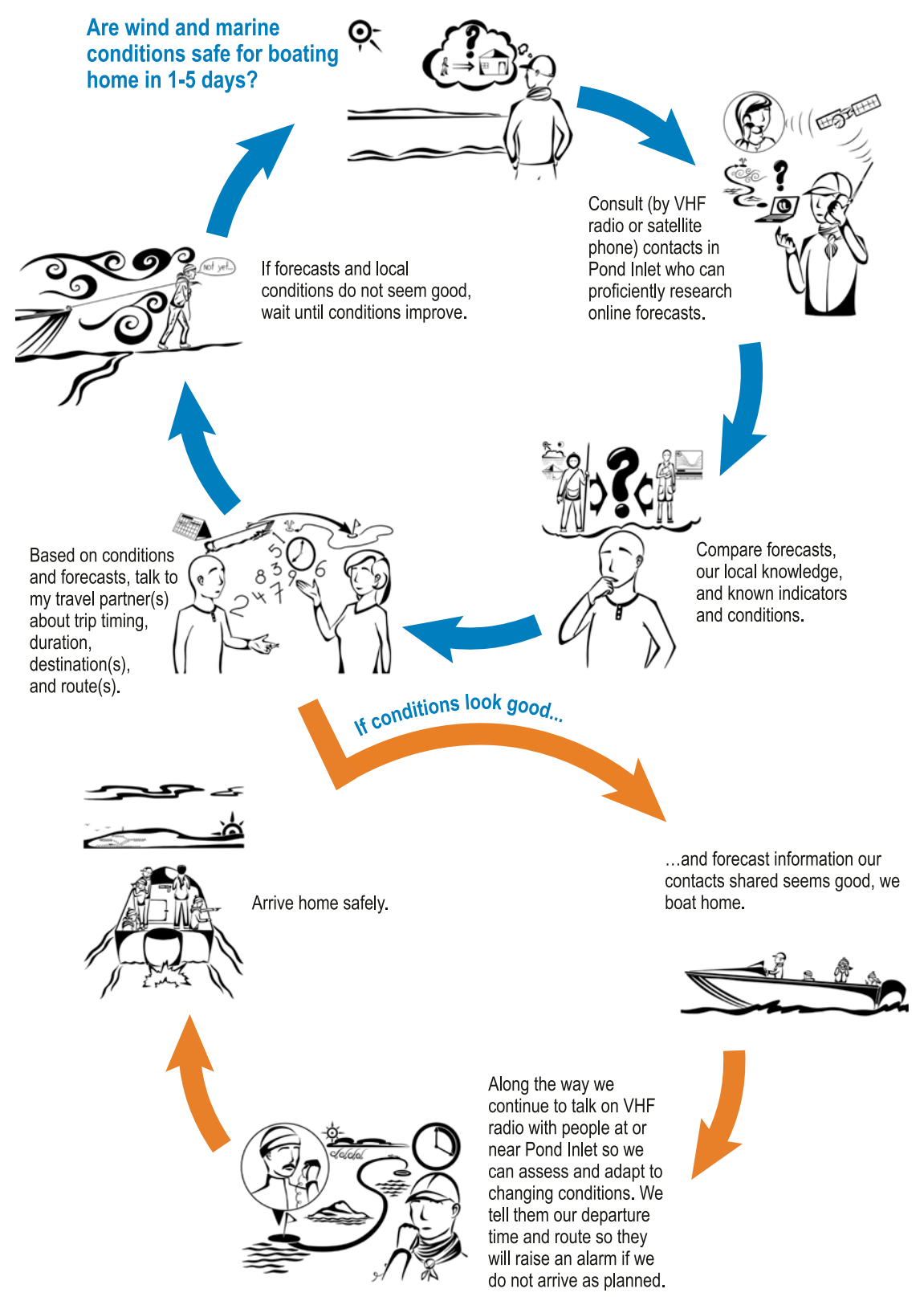

FIG. 6. Forecasting process to decide whether it is safe to travel to a new destination or return home by boat (illustrations by J. Itulu).

information into account to help us prepare, always bringing extra supplies in case our travel home is delayed with bad weather (Fig. 5). The planning process for leaving the community takes time; it can take between 1 and 5 days depending on weather and the gear and supplies we need. Once we get in our boat we are in constant communication with others, both those in town and out on the land (Fig. 5). We mainly use VHF marine radio to talk about what we are seeing and to get regular updates from others. This is also important so that people at or near our destination are aware of our travel plans and are expecting us in case of emergency (Fig. 5). For example, people will say, "Just so you know my computer said winds might be picking up tonight so you might want to pull your boat in" or "Heads up! Winds will be coming from tuluriangniqtuq (north-northwest) of us." Warnings are often given in a conversational or joking way, such as, "I hope you aren't running out of sugar because I don't think you're coming home for the next 3 days." However, they are taken seriously to ensure safety.

When we are already out boating or at camp, we need to make some slight adjustments to our forecasting process when deciding whether or not to return home (Fig. 6). This same process also applies if we are planning to travel to a new destination. When we are outside VHF radio or cellular range 
(Fig. 1), we must rely on satellite phones and community members in Pond Inlet to interpret online products for us. We will reach out to key people in town who we know are proficient in researching and interpreting wind, marine, and weather forecasts, as well as satellite imagery and other available environmental information online (Fig. 6). This helps us to assess conditions on our planned route, and what to expect near the community. Other than not being able to access online products ourselves while out on the land, our process of assessing conditions and consulting with people as we travel is the same as when we plan to leave Pond Inlet (Figs. 5 and 6).

\section{c. Communicating our local forecasts}

In our efforts to refine our forecasting process we have identified a number of factors that affect how each individual may interpret the information we share. We especially focus on language, but also potential differences in how community members understand weather, marine, and ice information. When we interpret and communicate environmental information, we must consider each traveler/hunter's degree of local Inuit knowledge. We also need to consider dialectal differences, which includes knowing where people originally come from and knowing the terminology they use. We also need to consider that people have picked up terms or meanings from other sources such as Canadian Broadcasting Corporation (CBC) news, which may affect the way a person understands or communicates weather information. For example, when describing wind direction in Inuktitut we do not use the words " north, east, south, west." When talking about wind direction locally, we use terminology that refers specifically to the place and direction that the wind is coming from. For example, if we have what might be called easterly winds in English we say "ilungmungniq." If winds are coming from Navy Board Inlet, which is north-northwest of us geographically, then we say "uangniq." Those are the two main ones for Pond Inlet. We also use different terms for wind depending on where we are, even if the wind is from the same cardinal direction, (i.e., an east wind in one place has a different term than an east wind in a different place). For instance, if you are in Milne Inlet or Tremblay Sound and the wind is coming from opposite the mouth of the inlet or sound, in English it would be described as westerly winds but in Inuktitut we say "pinnangnaq."

Facebook is heavily used by hunters and other community members when making travel plans, making it the preferred place to share forecasts and travel information and to reach a broad, relevant audience. Providing screenshots of satellite images from Polar View and Windy.com graphics decreases bandwidth usage by viewers, relative to if they accessed the full satellite image or watched the animated Windy.com graphics themselves. Given our slow and expensive bandwidth, by posting text and screenshots we make it easier for community members to access the information quickly and inexpensively (Figs. 7a,b).

The number one cause of miscommunication is "tukisinirlungniq" (when a person says something that is misconstrued by others). Knowing this, we need to do our best to communicate clearly about the information we have. Allowing for mistakes, it is in our best interest to continue doing what we do even though we do it on our own time and discretion. We do this work for the safety of others and for the purpose of modeling information sharing and passing on knowledge to young people. We have to continue.

\section{Strengths and challenges impacting our integration of weather, marine, and ice products in community forecasting}

No single scientific weather, marine, or ice product provides sufficient information to develop a fully informed community forecast or local travel plan. Rather, we must consult several weather, marine, and ice products repeatedly for up to one week prior to a potential trip. We also continue to rely heavily on our own knowledge, as well as word-of-mouth sharing of observations and advice from community members, in order to interpret available products. We have identified a number of unique strengths and challenges associated with integrating online environmental products in our community forecasting (Table 5).

\section{a. Strengths}

\section{1) INFORMATION ACCORDING TO RELEVANT GEOGRAPHIC AND SEASONAL COVERAGE}

Products that provide information at a local and regional scale around Pond Inlet, and according to different seasons, are particularly helpful for us. We travel year-round across a vast area (Table 3, Fig. 1), so products like Windy.com (Figs. 3a-d) that contain information for our entire area and in every season enable us to develop well-informed forecasts for any destination at any time. For appropriate geographic and seasonal coverage, we rely most on our own knowledge and observations, as well as word of mouth, to assess relevant weather, water, and ice conditions for the areas we want to travel to (Table 5).

\section{2) NEAR-REAL-TIME INFORMATION OR FREQUENT UPDATES}

Having access to information that is near-real time, or is updated frequently, means we can update and revise our forecasts repeatedly for a particular travel route or location we are planning on. Conditions often change very quickly as we travel and are very different at different times of year (Table 3). Accessing timely, up-to-date information can enable us to adapt to those conditions and travel more safely. Our local Inuit knowledge of environmental indicators and patterns, as well as word of mouth, are the sources we rely on the most for real-time and frequent updates on travel conditions (Table 5). We can really only use our own knowledge when we are traveling. When we are unsure, we call on others to provide their observations or advice.

\section{3) INFORMATION ON WIND AND ICE CONDITIONS IN DISTANT LOCATIONS}

Current conditions in our community may be very different from those along our travel route(s) and at our planned destination(s). So information about conditions (e.g., wind and ice) in places that we cannot see or otherwise know before traveling are very helpful to us when developing forecasts and 

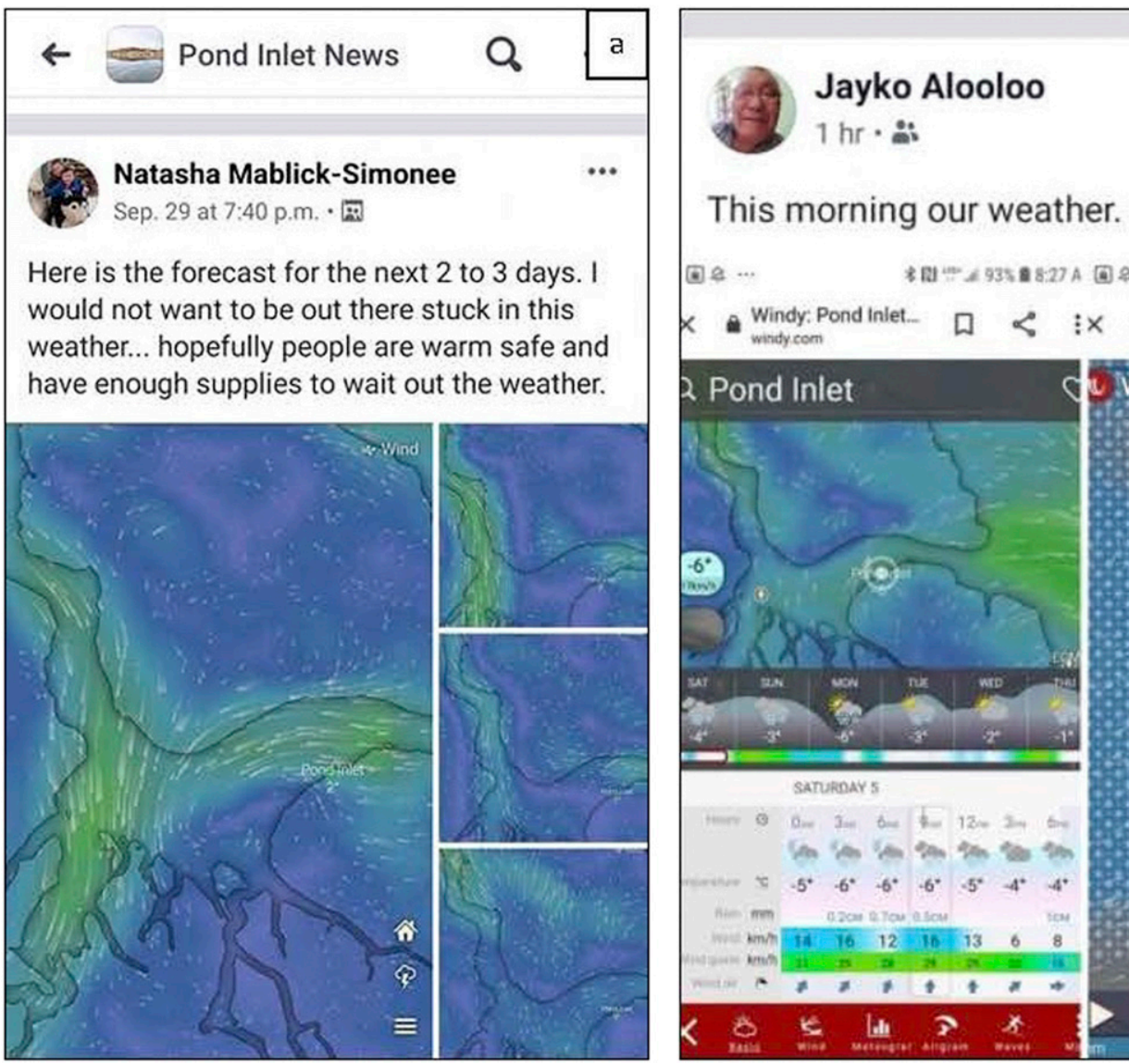

\section{This morning our weather.}

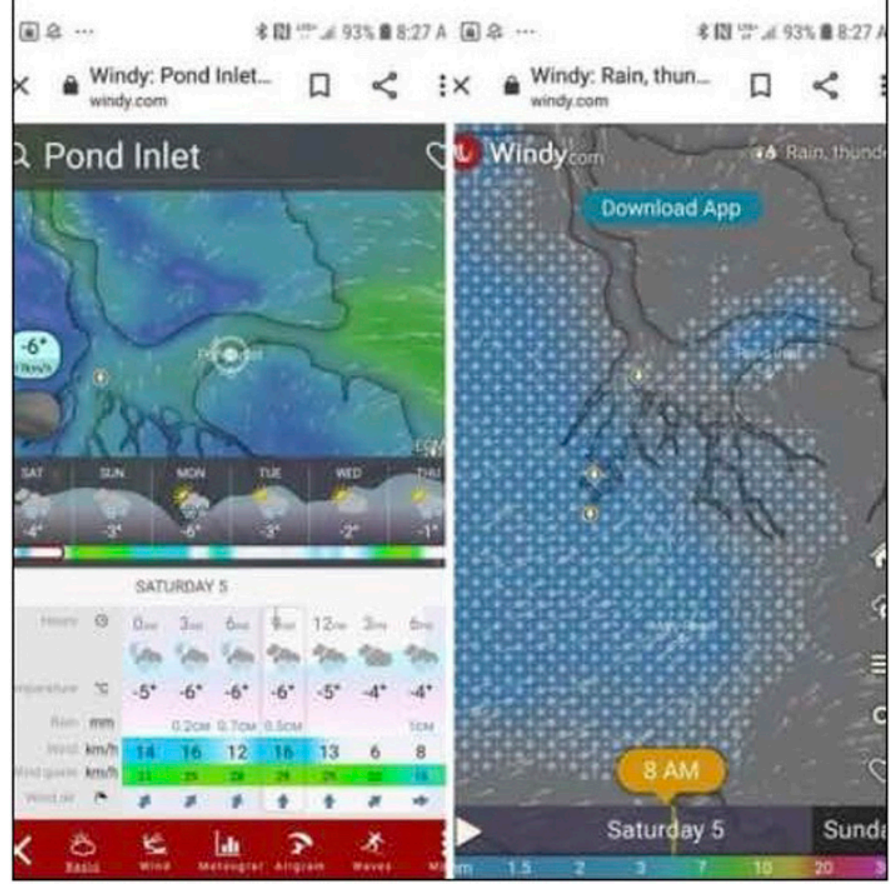

FIG. 7. Examples of forecasts shared on Facebook with fellow community members. (a) N. Simonee forecast posted in local Facebook group. (b) J. Alooloo forecast posted on personal Facebook page.

planning travel. Our local Inuit knowledge of patterns between geographical locations and connections between environmental indicators provides us with information about conditions in some distant locations (Tables 2, 5). Word of mouth is also very valuable, where people at or near our destination, or along our travel routes, can share information with us about environmental conditions they see. Windy.com wind forecasts, as well as ice information provided by Polar View, Zoom Earth, SmartICE, and Oceans North floe edge cameras, also help us to develop forecasts for distant locations and adjust travel plans accordingly (Table 5).

\section{4) OPTIONS TO CHANGE UNITS OF MEASUREMENT AND ZOOM IN TO AREAS OF INTEREST}

Knots are used as a measurement of speed in maritime navigation, but this unit of wind speed was not familiar to us and is not used locally. Products such as Windy.com that provide the option to change units of measurement (i.e., to $\mathrm{km} \mathrm{h}^{-1}$ or mph) make it much easier for us to understand and directly apply the information because we do not have to do the conversion ourselves (Table 5). This removes the possibility of making a mistake when doing mathematical conversions and avoids confusion for those who do not know how to accurately do these conversions. Products such as Windy.com and Zoom
Earth that enable us to zoom into areas of interest are also very helpful (Table 5). We especially like to be able to get a closer view of the floe edge position, or where leads are, to help us decide to avoid or visit particular travel routes or destinations. Having access to detailed, localized information means we can make more informed decisions about the (safest) routes to take and where we want to travel and hunt.

\section{5) USE OF COLOR TO DIFFERENTIATE BETWEEN FEATURES AND SCALES}

Products that use color to show different kinds of features and numerical scales make it much easier and faster for us to interpret the information and develop our forecasts. Products such as Zoom Earth (Fig. 4b) that distinguish between water (dark) and ice (white) make it easier for us to identify open water; information that is a matter of life and death for us when traveling on sea ice and across leads. Products such as SmartICE (Fig. 4c) that use color to show various levels of ice thickness and roughness, and Windy.com (Figs. 3a-d) that present wind speed according to a color scale, make us instantly aware of what conditions to expect. Visual ways of representing information means we do not have to do a lot of reading and the use of color makes interpreting the information more intuitive (Table 5). 


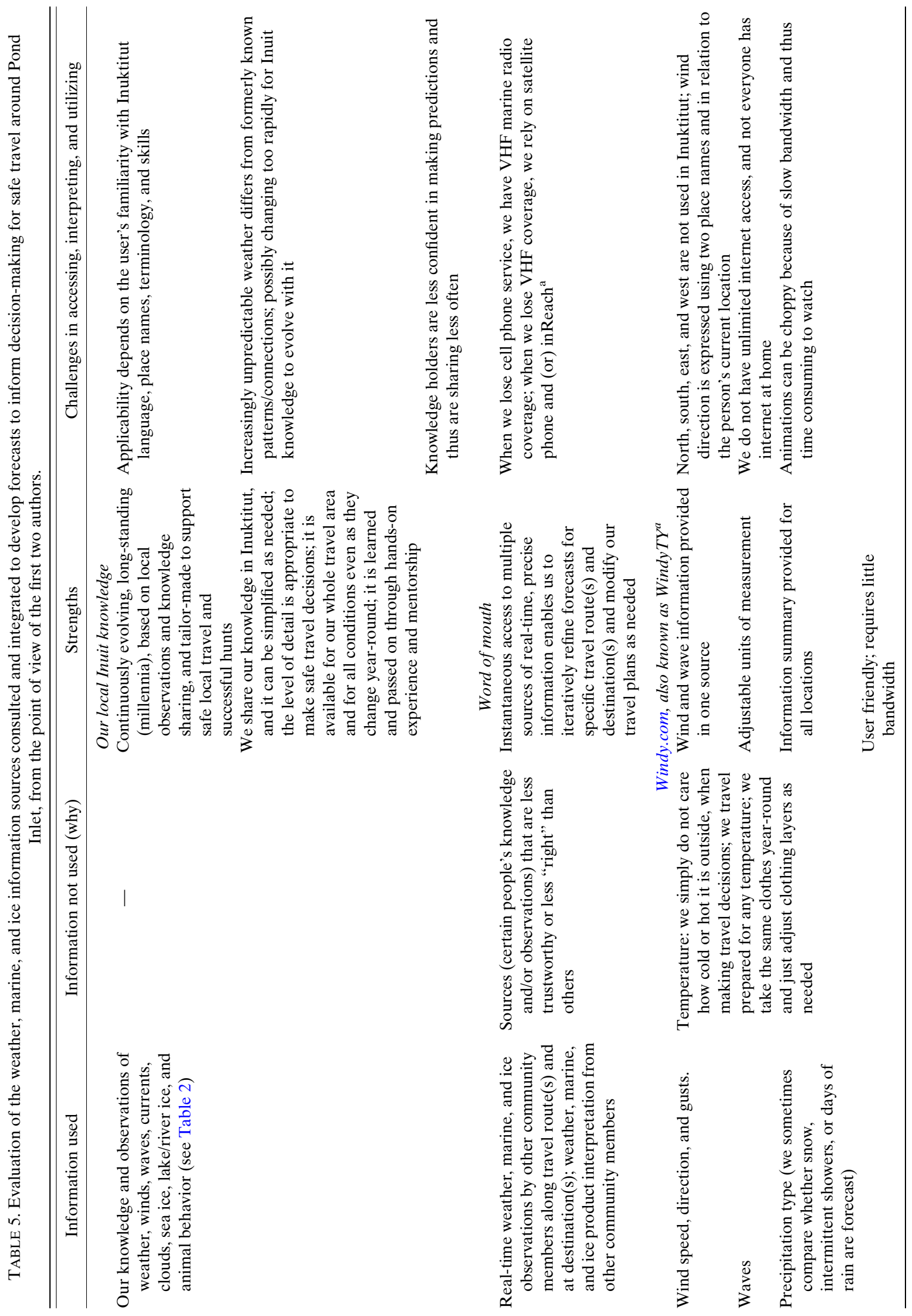



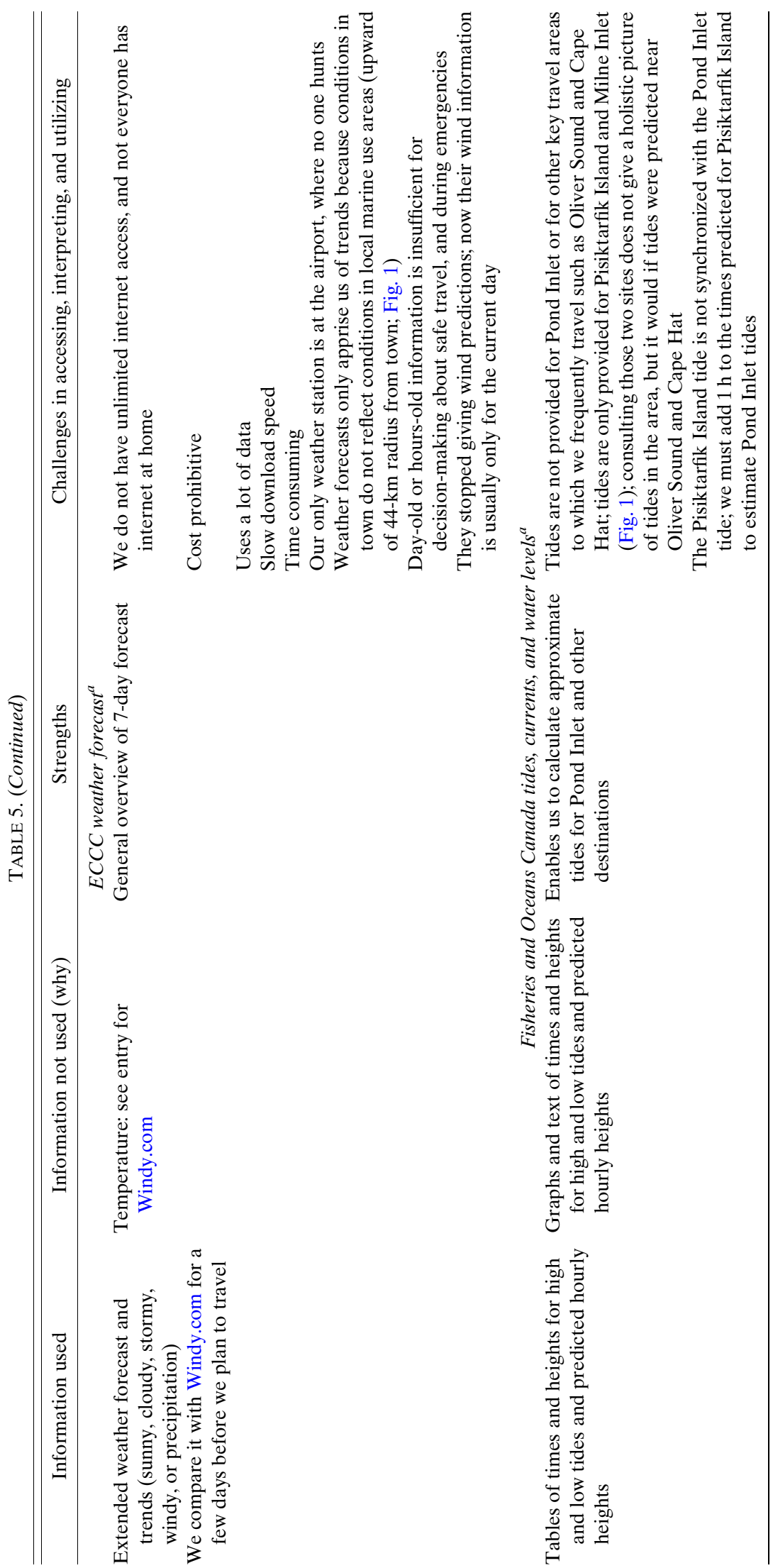


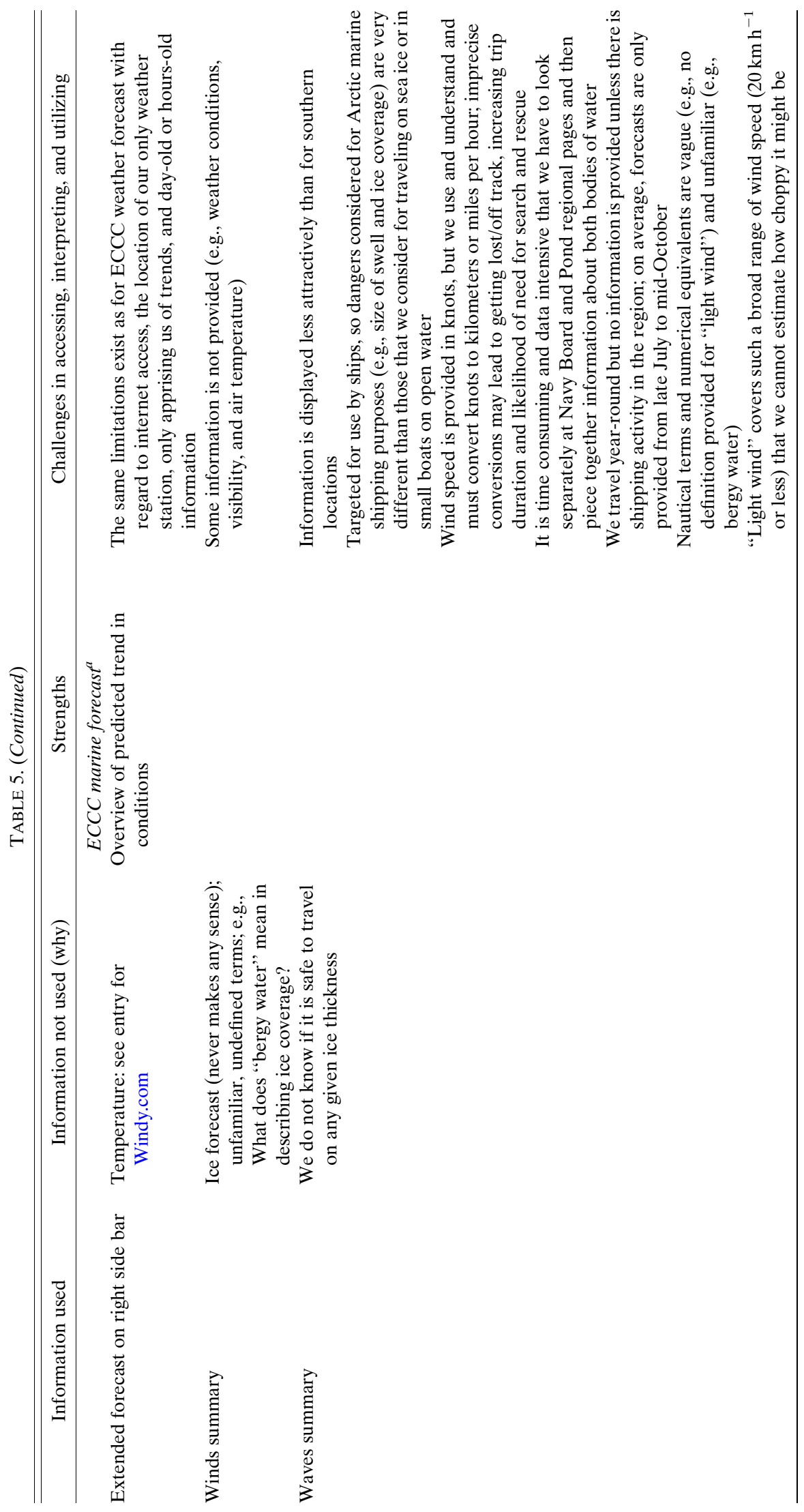




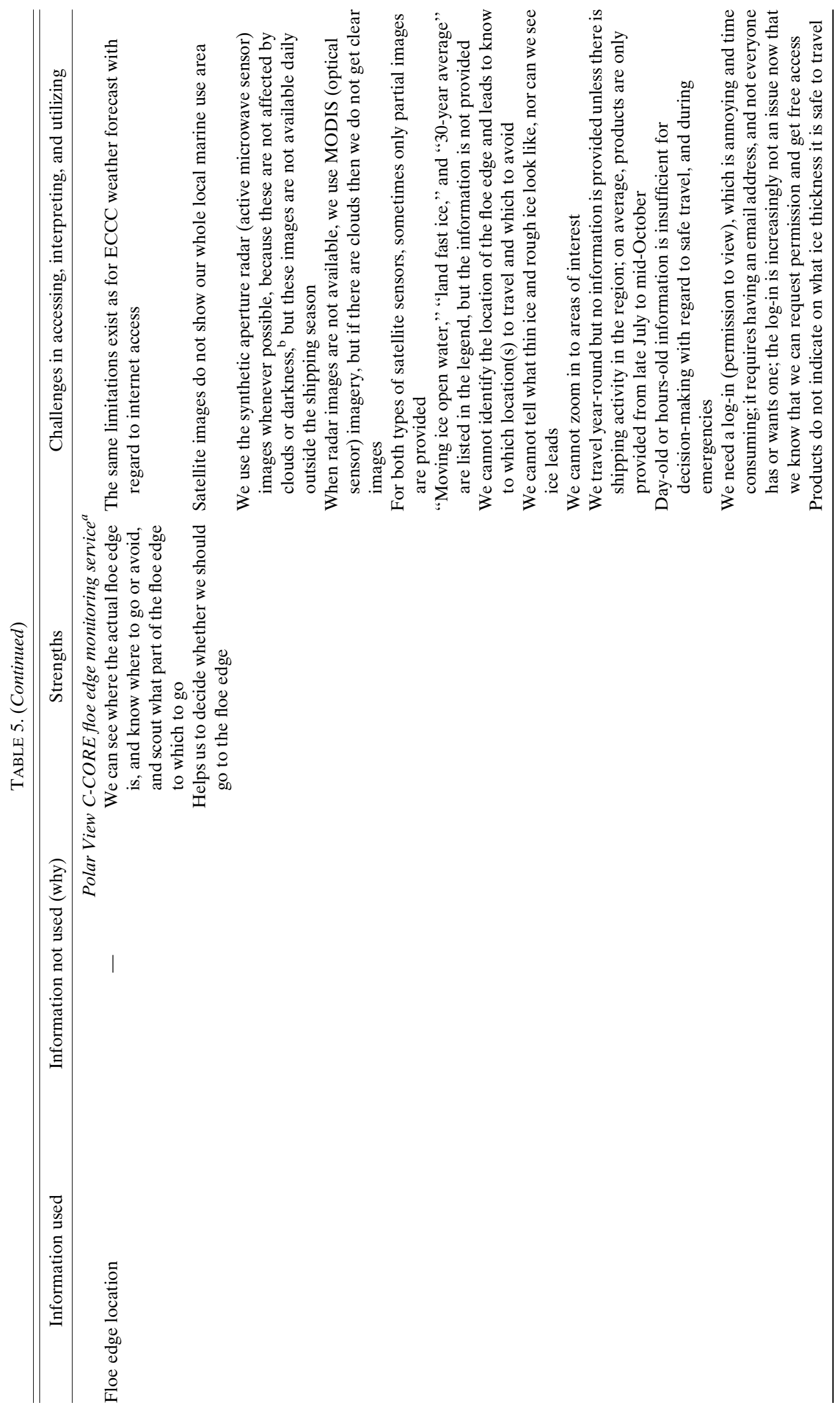




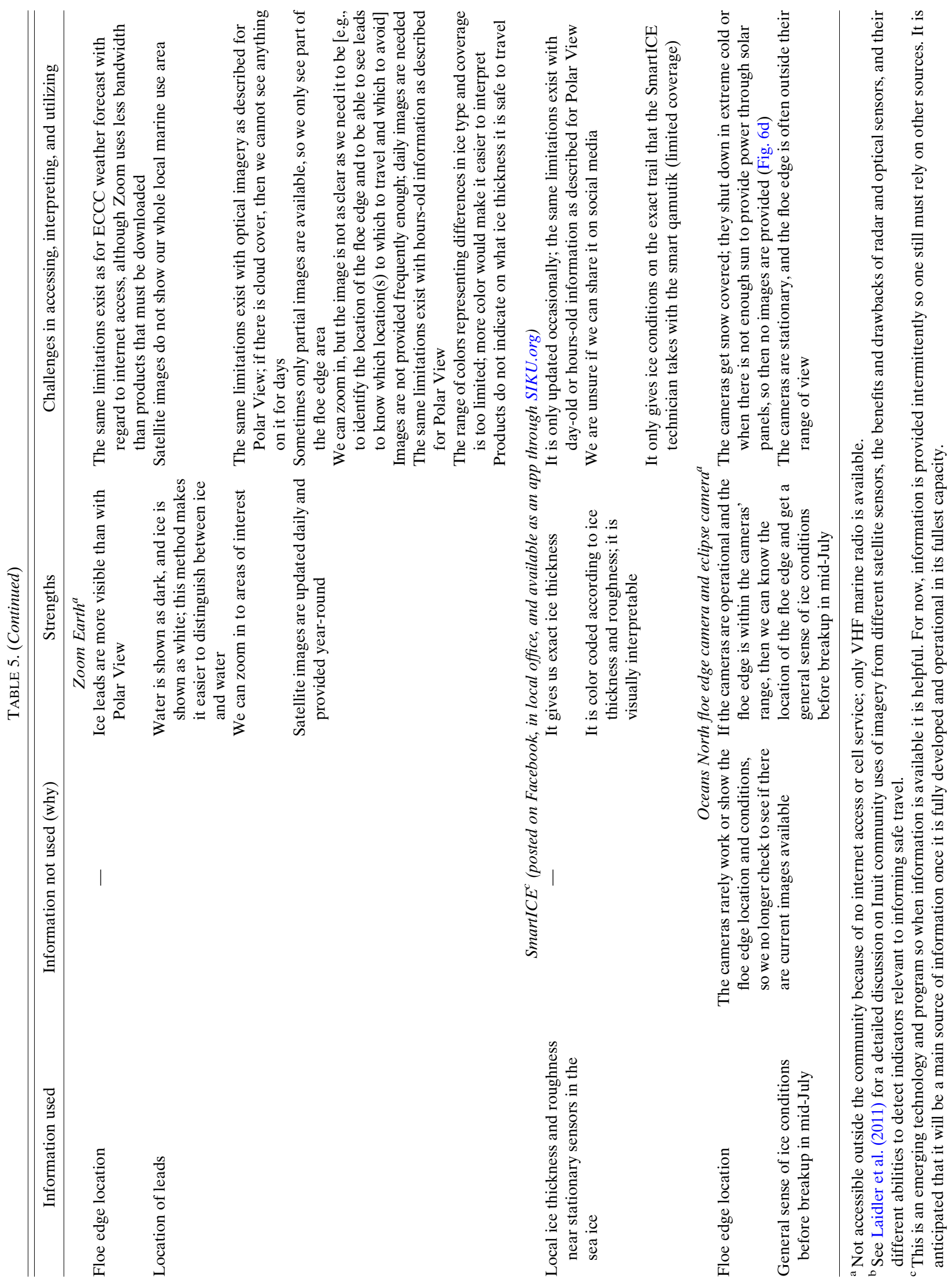




\section{b. Challenges}

\section{1) OVERLY DATA-RICH IMAGES}

A challenge we share with many Arctic communities is that not everyone has home internet access and for those who do, our internet access is limited, slow, and expensive. We pay around CAD $\$ 80$ per 25 gigabytes at a maximum download speed of 3 megabytes per second. Forecasting products and satellite images available to us are data-rich, often large files (e.g., over 5 megabytes) or use animations that require high bandwidth to stream (Table 5). We must wait for them to download, or for animations to update, which requires time and significant amounts of data.

\section{2) Having to CONSUlt MUltiple SOURCES}

We also spend a lot of time visiting multiple websites (and multiple pages within one website) to be able to access weather, water, and ice information that is relevant for the areas where we travel. Products for our marine use area (Fig. 1) are not provided all on one page or in a single source (e.g., marine forecasts for Navy Board and Pond are provided in two separate regional pages). To create our forecasts, we have to synthesize information from multiple pages and sources (Table 5). It is frustrating waiting for each page/product to load, it is time-consuming, and ultimately costs us more in buying data. Sometimes the information from different sources is also conflicting - telling us different things- which creates confusion about which product is more accurate and reliable to use. Not everyone has the analytical ability or experience needed to synthesize the information from multiple sources (see sections on converting units of measurement and terminology). Also, some services require an email address to create an account to view products (Table 5). Account requirements can create a barrier, as not everyone in our community has an email address. This is another reason why we develop our community forecasts: some people cannot access products directly. And, after submitting a registration request, we have to wait for permission to $\log$ in, which causes a delay in accessing the information.

\section{3) Having to do mathematical Calculations REQUIRED TO ADAPT INFORMATION TO MAKE IT LOCALLY RELEVANT}

The ECCC marine forecast expresses wind speed in knots. Knots are not used locally (see strength 4), which is challenging because not everyone understands that knots differ from kilometers per hour or knows how to convert knots to kilometers per hour (Table 5). Imprecise conversions may lead to getting lost or off track, which increases the trip duration and therefore the cost of food and gas and increases time away from family and/or wage employment. Hunters may not have enough supplies along for unexpected trip lengthening so the likelihood of needing rescuing also increases. Also, tides are not provided for Pond Inlet, so we have to estimate the Pond Inlet tide by adding $1 \mathrm{~h}$ to the times predicted for Pisiktarfik Island (Table 5).

\section{4) VAGUE OR UNFAMILIAR TERMINOLOGY}

Community members can access, read, and look at forecasts, but they do not necessarily understand them. For many hunters
English is their second language, they have limited formal schooling, and some are unilingual (Inuktitut-only speakers). When unilingual hunters ask for weather updates on the local VHF marine radio, not everyone has the vocabulary to translate the forecast into Inuktitut. If people do not fully understand what they are reading, trying to translate weather information becomes even more challenging and potentially dangerous. Similarly, the ECCC marine forecast terminology is vague (e.g., light wind) and uses unfamiliar terminology (e.g., bergy water) (Table 5). There are definitions of these terms available in the ECCC $(2019 a, b)$ online Weather and Meteorology Glossary. Light wind is defined as "Wind speed of $11 \mathrm{knots}\left(20 \mathrm{~km} \mathrm{~h}^{-1}\right)$ or less, with a Beaufort wind force of 0 to $4 . "$ Bergy water is defined as "Sea-ice terminology that describes an area of freely navigable water, in which ice of land origin is present. Other ice types may be present, although the total concentration of all other ice is less than 1/10." However, these definitions are not clearly linked from the marine forecast page, and they still include many technical terms and numerical references in the definition. Therefore, even the glossary does not help us to understand the relevance of the terminology to our local conditions.

\section{5) UNKNOWN RELATIONSHIPS OF INFORMATION PROVIDED TO LOCAL TRAVEL CONDITIONS AND SAFETY}

We do not always know the relationship between products and travel safety. For instance, satellite images do not indicate what ice thickness is safe to travel on (Table 5). The range of wind speeds or ocean conditions, such as "light wind" and "bergy water" mentioned above, do not tell us if marine conditions will be suitable for safe travel in our small boats (Table 5). Before Windy.com was available we always used the ECCC marine forecast. It was harder to make informed travel decisions with only this general forecast (Tables 5, 6). Terminology references were too vague to know what they meant for us when making travel decisions about our area.

We experience further challenges in interpreting forecasts related to wind direction. On CBC Radio when they announce the ECCC weather forecast in Inuktitut, they use Inuktitut terms when interpreting north, east, south, and west that do not apply to our local wind directions. Instead, they use terminology that is generalized for all of Nunavut, or certain regions of Nunavut. Similarly, CBC Radio might use the term "kanangnijaaqtu" when referring to ice fog in the winter, but that particular word is used less in Pond Inlet; we would likely use "kanangnamit" or "pinangnamit." So, we have to think about these things when we are deciding what to say in our own forecasts; we need to consider who we are talking to and their degree of local Inuit knowledge, as well as what they might have heard on CBC.

\section{6) INSUFFICIENT GEOGRAPHIC OR SEASONAL COVERAGE}

The regional forecast provided by the national weather service (the Meteorological Service of Canada in our case) is not relevant for the places to which we are actually traveling because the geographic scope and precision are insufficient. Like all communities in Nunavut, there is only one weather 
TABLE 6. Needs and disconnects between ice, marine, and weather products and local needs and uses around Pond Inlet, along with potential solutions.

\begin{tabular}{|c|c|c|}
\hline Local need & $\begin{array}{l}\text { Disconnect between products and local needs } \\
\text { and uses }\end{array}$ & Potential solution to meet local needs and uses \\
\hline \multirow[t]{4}{*}{ User-friendly } & $\begin{array}{l}\text { Must download data-rich images or stream } \\
\text { animated graphics }\end{array}$ & $\begin{array}{l}\text { Reduce image size but maintain sufficient quality for clear viewing; } \\
\text { include options to read text or stream animation vs download }\end{array}$ \\
\hline & $\begin{array}{l}\text { Must consult multiple pages of the same } \\
\text { website }\end{array}$ & Provide all information for local marine use area on one page \\
\hline & Must consult multiple products & Provide all necessary information in a single source \\
\hline & Must $\log$ in for view permission & Remove log-in requirements \\
\hline \multirow[t]{5}{*}{ Complete } & Insufficient geographic scope & $\begin{array}{l}\text { Provide all information for local marine use area on one page; } \\
\text { expand SmartICE coverage; provide satellite images of local } \\
\text { marine use area }\end{array}$ \\
\hline & $\begin{array}{l}\text { Only partial images are provided because of } \\
\text { cloud or snow cover }\end{array}$ & $\begin{array}{l}\text { Make ice leads visible; make thin ice and rough ice discernable; } \\
\text { have camera(s) within range of floe edge(s); keep lenses clean } \\
\text { and cameras working throughout floe edge season }\end{array}$ \\
\hline & Not available at certain times of year & $\begin{array}{l}\text { Provide weather, marine, and ice products for local use season; } \\
\text { have camera(s) within range of floe edge(s); keep lenses clean } \\
\text { and cameras working throughout floe edge season }\end{array}$ \\
\hline & Not available in real time & $\begin{array}{l}\text { Provide real-time wind, waves, currents, floe edge location, ice } \\
\text { thickness and roughness }\end{array}$ \\
\hline & Insufficient precision & $\begin{array}{l}\text { Increase local marine use area coverage precision (e.g., weather } \\
\text { stations in community-identified locations) }\end{array}$ \\
\hline \multirow[t]{4}{*}{ Locally applicable } & $\begin{array}{l}\text { Unfamiliar (meaningless) units of } \\
\text { measurement }\end{array}$ & Provide an option to display miles or kilometers per hour \\
\hline & Unfamiliar (meaningless) terminology & $\begin{array}{l}\text { Define nautical terms using nontechnical community-approved } \\
\text { vocabulary; provide numerical equivalents in miles and } \\
\text { kilometers }\end{array}$ \\
\hline & $\begin{array}{l}\text { Relationship to travel conditions and safety is } \\
\text { unknown }\end{array}$ & $\begin{array}{l}\text { Connect conditions with safe travel; support intergenerational } \\
\text { transfer of Inuit knowledge of weather interpretation, navigation } \\
\text { skills, and safety indicators }\end{array}$ \\
\hline & $\begin{array}{l}\text { Level of detail and definitions that allows } \\
\text { determination of whether the boats can } \\
\text { handle those conditions }\end{array}$ & $\begin{array}{l}\text { Provide detailed wind speed information (i.e., the range of wind } \\
\text { speeds that may occur in kilometers per hour) }\end{array}$ \\
\hline
\end{tabular}

station in our community, and it is located at the airport. However, no one hunts along the airstrip. So weather conditions recorded in town do not reflect the conditions in our local marine use areas (Fig. 1). In addition, ECCC budget reductions in the early 1990s resulted in many local weather offices being closed and fewer sea ice observations and predictions being provided (Bourgon 2009; G. McBean 2021, personal communication).

When looking at Polar View products, we cannot identify the location of floe edge(s) and leads because the image resolution is insufficient (Table 5). These are dangerous, high-risk areas. Hunters need to scout (see) where the actual floe edge and leads are to know to which location(s) to travel and which to avoid. If there is only one floe edge, hunters may decide not to go there, because there would be too many people. Having that information might save them a trip, and the cost of food, gas, and time away from family and/or wage employment.

Products such as ECCC marine forecast, and Polar View satellite images are only provided during the shipping season and are not available at other times of year (Table 5). However, we travel year-round except during freeze-up and breakup (Table 3). We need these products to be available year-round, and especially when there is a floe edge within our local travel area. Even during freeze-up (November, usually) it would be helpful to access images showing the areas of open water, so that we could monitor freeze-up. Until February we have a floe edge toward Button Point and every year people monitor the floe edge by traveling near to it, but satellite images are not available most of the fall and winter. Also, tides are not provided for Pond Inlet or other locations that we often travel to such as Oliver Sound and Cape Hat.

\section{7) INSUFFICIENT FREQUENCY OF UPDATES}

Forecasts are not provided in real time. Weather, marine, and ice conditions can change suddenly, rapidly, and unpredictably. Decision-making based on day-old or hours-old information is insufficient for decision-making with regard to safe travel, and during emergencies. Therefore, we often find ourselves testing the forecasts rather than relying on them. The forecasts are helpful to understand trends, but it is harder to use them for short-term planning and decision-making because actual conditions on the water, sea ice, and land are not provided. Because we are monitoring various products all the time, we get a sense of the trends and can still use them for planning and forecasting. However, if others only look at only one image or one source before they travel, they may not realize the information is out of date, or they may not have the knowledge needed to interpret it in the context of recent changes. 


\section{8) IRRELEVANT OR MISSING INFORMATION}

Several products include irrelevant information (e.g., temperature or ice forecast) and/or leave out relevant information (e.g., visibility, ice leads, our geographic-use area, moving ice, open water, landfast ice, and predicted tide height and times for Pond Inlet) (Table 5). Tides are not provided for Pond Inlet. The closest tides estimates are for Milne Inlet and Pisiktarfisk Island. We use MODIS imagery when radar images are not available but clear images are not provided if there is cloud cover when the image is taken (Table 5). Sometimes only partial images are provided for both radar and MODIS satellite sensors. Similarly, the Oceans North time-lapse cameras rarely work or show the conditions at the floe edge because the cameras shut down due to the extreme cold, or when there is not enough solar energy to power the cameras, or when they become snow covered (Table 5). Also, the cameras are stationary, so often the floe edge is too far away for the images to show its location or condition.

\section{9) LIMITS TO CELL PHONE AND VHF RADIO SERVICE}

Cell phone and VHF radio service are limited around Pond Inlet, and we travel much farther than existing coverage (Fig. 1). Once we travel outside the cell service area, we have to rely on VHF radio. Once we travel outside VHF radio coverage, we must rely on satellite phones or inReach to communicate. Beyond the cell service area, we cannot access online products ourselves, rather we must ask others to access them for us and relay the information back to us. This can be tedious and inefficient. We can only contact certain people to look up the information for us because they also need to be skilled in communicating and interpreting the products to enable us to make informed decisions.

\section{Addressing the disconnect between available products and community uses and needs}

Through our evaluation of various online environmental services, and feedback from our fellow community members, we have identified a disconnect between available products and our local needs. Our needs are specific to seasonal hunting activities and modes of travel (Table 3). We can only rely on our own local (Inuit) knowledge while we are traveling, and we value the knowledge of other community members who share their observations and safety advice (Table 2, 5). However, to us it is also important to be able to use a variety of environmental forecasting products to help in planning travel and deciding when to return home (Figs. 5, 6). We want to use the best available information to help evaluate conditions along our planned route, and to adjust to unpredictable weather. When products do not-or cannot-provide information relevant to our decision-making is where the disconnect happens.

What we need are weather, marine, and ice products that are user-friendly, complete, and locally applicable (Table 6). Here we discuss the overarching challenges creating the disconnect, and we offer several potential solutions that could help to better serve not only Pond Inlet, but other Inuit communities with similar needs. Our community-specific analysis also reflects the gap between climate science, climate/weather services, and decision-making that has been identified in other Arctic (Laidler et al. 2011; Baztan et al. 2017; Kettle et al. 2017; Steiro et al. 2021) and international (Barihaihi and Mwanzia 2017; Green et al. 2010; Chambers et al. 2019) contexts. Although our suggestions for addressing the disconnect have a particular focus on polar regions, we encourage service providers to consider how they could also be adapted and tailored to support environmental forecasting for Indigenous communities in other parts of the world.

\section{a. User-friendly}

Every day we use a number of weather, marine, and ice products and forecasts (Table 4), but not all of these are userfriendly (Table 6). Numerous challenges exist with regard to the local usefulness of these products in Pond Inlet (Table 5, 6), and in other Inuit communities (Shirley 2006; Gearheard et al. 2010, 2020; Laidler et al. 2011; Eicken 2013; WMO 2017; Panikkar et al. 2018). Sophisticated dynamic interfaces are not accessible to most community users (Stewart et al. 2020). As Thoman et al. (2017, p. ES3) point out "[i]mproved modeling and more technology are sometimes assumed to be inherently 'better,' but if end users do not use, or cannot access, the information, they are not better in a societal sense." Basically, great technologically advanced products are not helpful if we cannot access, interpret, and use them.

Overarching challenges that affect the useability of products in Pond Inlet include data-rich imagery (challenge 1), having to consult many sources to synthesize important information, and requirements for user accounts to access information (challenge 2) (Tables 5, 6). We have developed a systematic approach to interpreting and synthesizing this information to share with our fellow community members. However, for others wanting to use this information directly it can be frustrating to try to find what they are looking for.

The user-friendly aspect of environmental forecasting products has not been specifically addressed in much literature involving partnerships with Inuit communities. Alaska leads the way in this area, where hunters and whalers have identified similar challenges as we have, related to limited internet bandwidth; reliability of weather, water, and sea ice products for community use; and having to go to many distribution portals to access relevant information (Eicken 2013; WMO 2017; Kettle et al. 2020). However, limited internet access and low bandwidth is also a common challenge identified in a variety of marine activities in polar regions (e.g., cruise tourism, shipping, fisheries, and government and research operations; Lamers et al. 2018; WMO 2017; Jeuring et al. 2020; Stewart et al. 2020), as well as in other Indigenous communities (Masinde 2015; Chambers et al. 2019; Kaiser et al. 2019). To develop user-friendly products, service providers need to address the challenges of "knowing users" and to gain an "embedded understanding of their needs" (Jeuring et al. 2020, p. 148; and see Eicken 2013). There also needs to be more recognition of the difference between the automated provision of data and products developed by operational forecasters, as well as the value (and limits) of different visualizations based on the same underlying models (Jeuring et al. 2020). Training in interpreting 
satellite imagery would be helpful (e.g., the difference in what synthetic aperture radar such as RADARSAT satellites show as compared with optical imagery such as MODIS) (Laidler et al. 2011). To enable effective data interpretation information needs to be communicated "simply, efficiently, and effectively in a language that is understandable for the users" (Stewart et al. 2020, 109). To tailor forecasts to meet user needs in Inuit communities, service providers need to better understand how and what Inuit seek to interpret from forecasting products.

The specific challenges we have identified in Pond Inlet (Table 5) can be addressed by service providers: i) organizing information according to marine use areas (ideally in one source and on one page); ii) providing images that are clearly visible but of reduced size; iii) offering text or streaming options instead of download-only; and iv) removing requirements to $\log$ in to access products (Table 6). Broadly, we suggest that services could be more user-friendly if

- data needs are reduced to accommodate low bandwidth and expensive cellular data, without compromising image quality or detail of information;

- more training and support are provided to improve interpretation of products and increase access to computers/mobile devices; and

- user-friendly platforms are developed to provide access to multiple products and relevant information in one spot.

\section{b. Complete}

When we consult environmental forecasting products, we are mostly interested in short-term forecasts and seasonal trends, as well as conditions at the places we want to travel to. Among the biggest challenges in this regard are insufficient geographic and seasonal coverage (challenges 6 and 7) and irrelevant or missing information (challenge 8) (Tables 5, 6). These challenges of scale/resolution, frequency of coverage, and relevant geographic regions of interest based on marine use area have been identified in other Inuit communities (Druckenmiller et al. 2009; Laidler et al. 2011; Eicken 2013; Lovecraft et al. 2013). For example, in Kinngait, Igloolik, and Pangnirtung, Nunavut, they identified that sea ice conditions of main concern for travel safety (e.g., tidal cracks, leads, small polynyas, and the amount of new ice growth at the floe edge) would require satellite imagery with higher resolution than was publicly available at the time (Laidler et al. 2011). In Alaska, the need to tailor sea ice observations and predictions to particular users is emphasized by Eicken (2013, p. 432): "The stages of 'new ice' that are considered hazardous by regulators, safe to walk on by the Iñupiaq people, detectable through remote sensing or capable of damaging coastal structures vary by days." Locally relevant environmental indicators are rarely provided at the appropriate spatial and temporal scale to meet community or other maritime navigation needs (Stewart et al. 2020). The interest in having nearreal-time observations is also common across Arctic regions in order to support decision-making in dynamic sea ice environments (Druckenmiller et al. 2009; WMO 2017; Fox et al. 2020; Kettle et al. 2020; Stewart et al. 2020). Establishing webcams and/or weather stations at important locations can be useful in providing real-time information to assess relevant water or ice conditions (Druckenmiller et al. 2009; Panikkar et al. 2018; Fox et al. 2020). As we experience in Pond Inlet, however, there can be issues with webcam visibility (i.e., in darkness or if cameras become snow covered) and continuity (i.e., if equipment fails or funding to maintain the cameras and data feeds runs out) (challenge 8) (Table 5). We also currently lack additional weather stations beyond the local airport.

The challenges we face in our experience (Table 5) can be addressed by service providers working to expand their geographic and temporal (including real-time) coverage. This includes developing products that account for our entire local travel area and seasons of interest, at sufficient resolution to use in our decision-making (Table 6). This also relates to userfriendly considerations of ensuring that marine use areas are covered in one source and on one page. Broadly, we suggest that services could be more complete if

- effective coverage of land/marine use areas is provided;

- year-round coverage reflects seasonal activities;

- real-time or frequently updated forecasts are provided;

- coverage of instrumental monitoring is increased to support local/regional forecasts; and

- effort is dedicated to developing innovative networked approaches to incorporating community-based monitoring and local observations into forecasting.

\section{c. Locally applicable}

Most important, for environmental forecasting products to be relevant and valuable to us, they need to be locally applicable. Some aspects of this we already covered in earlier sections about having user-friendly and complete products. Including the relevant land/marine use area is critical, and so is sufficient resolution to identify important places and conditions (Table 6). In addition, the terminology and units of measurement need to be clear and understandable (challenge 4) (Table 6). To be locally applicable, we also need to be able to identify and assess relevant environmental indicators in a way that helps us understand the relationship between information provided and our local travel conditions and safety concerns (challenge 5) (Table 6). Not all hunters can apply weather, marine and ice product information to decide if it is safe to travel, so we encourage service providers to learn more about what is locally relevant across diverse northern regions and needs.

Although the environmental indicators we look for are individually important (Table 2), it is not only about identifying relevant conditions but using them all together to make an informed decision for circumstances at hand (Table 3 ). This will vary based on decision thresholds, perception of risk, capacities, and constraints within the context of individual knowledge and experience (WMO 2017; Kettle et al. 2020; Stewart et al. 2020). Just to the south of us, on the east coast of Baffin Island, the community of Clyde River is leading the way in identifying human-relevant environmental variables (HREVs) to inform weather forecasting in an Inuit context (Fox et al. 2020). Their work shows that HREVs such as 
visibility, blowing snow, and wave height tend to be more important than any individually measured meteorological variable such as air temperature and wind speed. Our experiences are closely reflected in Fox et al.'s (2020, p. 273) effective explanation:

Inuit regularly view the natural system by combining relatively simple pieces of information into more complex variables (i.e., HREVs) that relate directly to hunting, fishing, travel, and safety in all outdoor and livelihood activities. These HREVs, in turn, are used in conjunction with a host of social variables (e.g., who is travelling, what they are travelling for, what else is occurring in their lives) to inform decisions that enable safe, productive, and life-affirming travel on land, open sea, and ice.

Wind is one of the most important weather variables for navigation in polar regions as it contributes to extreme events, rapid movement or breakup of ice, poor visibility, high waves, among other dangerous conditions (Lamers et al. 2018; WMO 2017; Stewart et al. 2020). Inuit talk a lot about wind as a critical factor in making travel decisions (Laidler et al. 2009; Gearheard et al. 2010; Weatherhead et al. 2010; Eicken et al. 2014; Fox et al. 2020), and so do tourism, commercial fishing, and shipping vessel operators (Lamers et al. 2018; WMO 2017; Stewart et al. 2020). It is also one of the hardest variables to predict, and there is a lack of good wind data and forecasting tools (Gearheard et al. 2010; Stewart et al. 2020). Windy.com has done a great job of making wind data accessible and easy to interpret with their animations of wind direction and speed. It has become very useful to us, but only after we did a series of iterative evaluations to connect what we see online with marine conditions in our area. Our example of Windy.com revising the user interface (color coding, type of units, and creating an app) demonstrates how service providers can update their products to make them more accessible and relevant to our needs. Windy.com is also a good example in which a provider has taken available data and developed a visualization and user interface that is easy to access and interpret. Although the raw model data are no different (or better) than any other service provider is using, it has become popular around the world because it is userfriendly and locally relevant in many contexts ( $R$. Thoman 2018, personal communication).

For service providers to include more locally applicable variables and scales (with regards to time and location) in their forecasts, there needs to be more recognition of community research leadership already taking place across Inuit communities. More opportunities for direct two-way communication between Indigenous knowledge holders and local experts, with scientists and service providers, is also needed. Along with this, work needs to be done to adjust institutional and individual attitudes to take community input more seriously, and to consider the holistic and cultural context to tailor environmental forecasts to be more relevant according to regional priorities. A starting point in addressing some of the challenges we identified include service providers being able to provide options to change units of measurement (or provide numerical equivalents in kilometers per hour and miles per hour), as well as detailed ranges of predicted wind speed (challenge 3 ) (Table 6). Clearly defining nautical and other specialized terms using community-approved vocabulary would also help to make products more locally relevant (challenge 4) (Table 6). Although we interpret available information in light of our own experiences and knowledge (also see Laidler et al. 2011; Fox et al. 2020), it would still increase the relevance of available products if relationships between weather, marine, and ice information and safe travel were made clearer (challenge 5). Services and products that support Inuit knowledge sharing between generations and communities would also increase how applicable the information is to us. Broadly, we suggest that services could be more locally applicable if

- appropriate (understandable) units of measurement are provided according to the region of interest and intended use;

- clear and accessible language is used according to the region of interest and intended use, including plain English and relevant Indigenous language(s);

- the importance of local observations and traditional forecasting approaches, the value of word-of-mouth communication, and limits to technology are recognized; and

- programs that foster intergenerational transfer of Indigenous knowledge of weather interpretation, navigation skills, and local indicators for travel safety are supported and expanded.

\section{Our suggestions for moving forward}

In our experience, weather, marine, and ice forecasts are most accurate when online information and local Inuit knowledge are combined. Relying solely on technology is not enough to make safe travel decisions. Technology can only complement place-based and cultural knowledge; it cannot be used alone-or used effectively-without intergenerational and experiential knowledge. Survival skills and local Inuit knowledge are critically important in adapting to weather and ice conditions that are increasingly unpredictable. Environmental forecasting or instrumental observations cannot replace Inuit weather and ice interpretation, they are just one piece of information used in our decision-making processes. This point is already widely recognized in the literature (Laidler et al. 2011; Eicken et al. 2014; Fox et al. 2020; Stewart et al. 2020; Wilson et al. 2021). Without the knowledge and experience on the land, ice, and water, along with technical skills and resources, it is difficult to interpret online environmental products in meaningful ways. Nevertheless, it is still helpful if environmental information provided can be directly relevant to Inuit decisions and actions (Fox et al. 2020).

We often feel stuck in the middle between traditional knowledge and modern services, trying to determine what information is most reliable, and trying to answer questions that our fellow community members ask us. It is vitally important that all aspects of weather, season, mode of travel, purpose, and destination are fully considered (Table 3 ). This means that local Inuit knowledge and skills related to environmental observation, navigation, and safe travel remain central in our decision-making (Table 5). This is crucial in avoiding potential dangers and accidents. Inuit still use some of the traditional decision-making today, but we are also now combining these skills with information available through online environmental 
products. In developing our community forecasts, we employ a number of adaptations in using weather, marine, and ice products to make decisions about safe travel around Pond Inlet. These include 1) consulting multiple information sources over several days; 2) interpreting results in conjunction with our local Inuit knowledge and in consideration of the intended audience; 3 ) ground truthing to develop and enhance a "mental database" comprising local Inuit knowledge, weather, marine, and ice information along with real-time observations; and 4) communicating images and summary text on social media (in English and Inuktitut) and verbally over VHF marine radio (in Inuktitut).

For someone in the government or in a company, it is their job to interpret images, develop products, and post pictures or environmental information. To us, however, these are more than just pictures. We, and our fellow community members, are relying on this information. Each service we consult has a different role in informing our decisions, but we have to work so hard to obtain and use all the information we think is important. We suggest this is about equity. If service providers could understand how much we rely on this information, any product improvements to meet our needs would be more beneficial than they might think. This is in part why we wrote this paper. We hope it encourages or inspires other to write about their own experiences, because there are others who can relate. And maybe there are others who have already overcome some of these challenges and we can learn from each other. Synthesizing relevant environmental variables, and using them in fast-changing marine environments, is often a matter of life and death (Eicken 2013; Fox et al. 2020; Stewart et al. 2020). We want to keep ourselves, our families, and our fellow community members safe; this is why we do what we do.

Our experiences echo the calls across polar regions for flexibility in tailoring environmental services to meet societal needs (Eicken 2013; WMO 2017; Lamers et al. 2018; Thoman et al. 2017; Stewart et al. 2020). Meeting our local needs - among other diverse needs-requires environmental forecasting products to be user-friendly, complete, and locally applicable according to the cultural and geographic context. To address the disconnect between challenges we face, and our community forecasting needs, we propose several solutions that involve

1) adapting products to accommodate low bandwidth;

2) providing training and support for product/image interpretation;

3) developing user-friendly platforms that enable access to multiple sources of information in one place;

4) working with experienced hunters and travelers to identify relevant land/marine use areas to provide appropriate seasonal coverage;

5) updating products as often as possible;

6) improving the coverage of instrumental monitoring (e.g., more weather stations outside the community);

7) connecting community-based monitoring with broader regional forecasting programs;

8) using clear and understandable language and units of measurement; and
9) supporting and expanding programs that foster intergenerational transfer of Indigenous knowledge.

Many of our proposed solutions are very practical and achievable with current products and technology, it just requires some effort and investment by service providers to refine for community relevance. Other proposed solutions may be more difficult to achieve because the information needed is simply not available with current products and technologies (i.e., the temporal coverage or spatial resolution is unavailable). However, we cannot move forward alone, and neither can researchers and service providers. As Fox et al. (2020, p. 277) highlight, "[c]ollaborations are essential for going beyond the limitations of individual expertise. A strong team recognizes the respective contributions of its members and builds on strengths while also sharing knowledge to improve areas of weakness.' Partnerships across communities, governments, private companies, nongovernmental organizations, and academics have been critical in moving toward more of an Arctic-system-science approach (Eicken et al. 2009; Gearheard et al. 2010; Eicken 2013; Lovecraft et al. 2013; Kettle et al. 2020; Fox et al. 2020). This is already being clearly demonstrated in services that we use such as SmartICE, Oceans North time-lapse cameras, and Polar View. Other examples we know of that combine localized sea ice and weather monitoring instrumentation with community-based monitoring activities and Inuit knowledge include the following:

- SIKU-The Indigenous knowledge social network (https:// siku.org);

- the Clyde River Weather Station Network (https:// www.clyderiverweather.org);

- Ujjiqsuiniq monitoring in Arviat (https://www.aqqiumavvik.com/ young-hunters-program?);

- Ocean Networks Canada Community Observatory in Cambridge Bay (https://www.oceannetworks.ca/learning/ ocean-sense/community-observatories/cambridge-bay);

- the Alaskan Sea Ice for Walrus Outlook (https://www.arcus.org/siwo);

- Seasonal Ice Zone Observing Network and Alaska Arctic Observatory and Knowledge Hub (https://eloka-arctic.org/ sizonet/); and

- several community-research partnerships (Druckenmiller et al. 2009; Eicken et al. 2009; Lovecraft et al. 2013; Bell et al. 2014; Fox et al. 2020; Segal et al. 2020; Wilson et al. 2020), to name just a few.

You would think we (modern Inuit) would make better and more informed decisions as a result of access to technology and more environmental information, but we are not doing that. The predictions we are making to inform safe travel are not as good as they were 30 years ago. We will never decide to travel on the basis of online weather and marine product information only. We may decide to travel based on local Inuit knowledge and observations of weather alone, but it is best when both sources of information are used. That is why any effort to make environmental forecasting products more user-friendly, complete, and locally applicable is valuable-it could save lives. 
Acknowledgments. The authors are grateful for the financial and in-kind support for writing this paper provided by ArcticNet NCE, Clear Seas, Environment and Climate Change Canada, Irving Shipbuilding Inc., Canada Research Chairs Program, and MEOPAR NCE. We thank Brian Koonoo and Martin Visser for providing VHF marine radio coverage data; Regena Sinclair for preparing Figs. 1 and 3a; Oceans North for providing eclipse and floe edge camera locations; Trevor Bell for providing the SmartICE/SIKU image for Fig. 4c; Jamesie Itulu for creating the drawings for Figs. 5 and 6; as well as James Simonee, Katherine Wilson, Tracy Westell, Christine Higdon, Gordon McBean, and Rick Thoman for technical support. We also thank Robert Way, Henry Huntington, and two anonymous reviewers for their valuable feedback, which strengthened our paper. Photograph credits: Natasha Simonee.

\section{REFERENCES}

Barihaihi, M., and J. Mwanzia, 2017: Enhancing farmers' resilience and adaptive capacity through access to usable weather information: A case study from Uganda. Climate Change Adaptation in Africa Fostering Resilience and Capacity to Adapt, W. L. Filho et al., Eds., Springer, 617-627.

Baztan, J., M. Cordier, J.-M. Huctin, Z. Zhu, and J.-P. Vanderlinden, 2017: Life on thin ice: Insights from Uummannaq, Greenland for connecting climate science with Arctic communities. Polar Sci., 13, 100-108, https://doi.org/10.1016/j.polar.2017.05.002.

Beaumier, M. C., and J. D. Ford, 2010: Food insecurity among Inuit women exacerbated by socioeconomic stresses and climate change. Can. J. Public Health, 101, 196-201, https://doi.org/ 10.1007/BF03404373.

Bell, T., R., Briggs, R. Bachmayer, and S. Li, 2014: Augmenting Inuit knowledge for safe sea-ice travel-The SmartICE information system. 2014 Oceans-St. John's, St. John's, NL, Canada, IEEE, https://doi.org/10.1109/OCEANS.2014.7003290.

Bourgon, J., 2009: Program review: The Government of Canada's experience eliminating the deficit, 1994-1999-A Canadian case study. The Centre for International Governance Innovation Doc., 32 pp., https://www.cigionline.org/sites/default/files/the_ government_of_canada_s_experience_eliminating_the_deficit_ 1994-99.pdf.

Carter, N. A., J. Dawson, J. Joyce, A. Ogilvie, and M. Weber, 2018: Arctic corridors and northern voices: Governing marine transportation in the Canadian Arctic. University of Ottawa Pond Inlet, Nunavut Community Rep., 32 pp., https://doi.org/ 10.20381/RUOR37271.

CBC, 2013: 24 people rescued from ice floe near Pond Inlet, Nunavut. CBC News, https://www.cbc.ca/news/canada/north/24-peoplerescued-from-ice-floe-near-pond-inlet-nunavut-1.1354250.

_- 2015: Missing Pond Inlet man walks safely into Repulse Bay. CBC News, https://www.cbc.ca/news/canada/north/missing-pondinlet-man-walks-safely-into-repulse-bay-1.3080163.

Chambers, L., and Coauthors, 2019: Traditional or contemporary weather and climate forecasts: Reaching Pacific communities. Reg. Environ. Change, 19, 1521-1528, https://doi.org/10.1007/ s10113-019-01487-7.

Chand, S. S., L. E. Chambers, M. Waiwai, P. Malsale, and E. Thompson, 2014: Indigenous knowledge for environmental prediction in the Pacific Island countries. Wea. Climate Soc., 6 , 445-450, https://doi.org/10.1175/WCAS-D-13-00053.1.

Clark, D. G., J. D. Ford, L. Berrang-Ford, T. Pearce, S. Kowald, and W. A. Gough, 2016: The role of environmental factors in search and rescue incidents in Nunavut, Canada. Public Health, 137, 44-49, https://doi.org/10.1016/j.puhe.2016.06.003.

Druckenmiller, M. L., H. Eicken, M. A. Johnson, D. J. Pringle, and C. C. Williams, 2009: Toward an integrated coastal sea-ice observatory: System components and a case study at Barrow, Alaska. Cold Reg. Sci. Technol., 56, 61-72, https://doi.org/ 10.1016/j.coldregions.2008.12.003.

Durkalec, A., C. Furgal, M. W. Skinner, and T. Sheldon, 2014: Investigating environmental determinants of injury and trauma in the Canadian north. Int. J. Environ. Res. Public Health, 11, 15361548, https://doi.org/10.3390/ijerph110201536.

ECCC, 2019a: Light wind. Weather and Meteorology Glossary, Government of Canada, https://www.canada.ca/en/environmentclimate-change/services/weather-general-tools-resources/glossary.html\# wsglossaryL.

_ $2019 \mathrm{~b}$ : Bergy water. Weather and Meteorology Glossary, Government of Canada, https://www.canada.ca/en/environmentclimate-change/services/weather-general-tools-resources/glossary.html\# wsglossaryB.

Eicken, H., 2013: Arctic sea ice needs better forecasts. Nature, 497, 431-433, https://doi.org/10.1038/497431a.

— A. L. Lovecraft, and M. L. Druckenmiller, 2009: Sea-ice system services: A framework to help identify and meet information needs relevant for Arctic observing networks. Arctic, 62, 119-136, https://doi.org/10.14430/arctic126.

—, M. Kaufman, I. Krupnik, P. Pulsifer, L. Apangalook, P. Apangalook, W. Weyapuk Jr. and J. Leavitt, 2014: A framework and database for community sea ice observations in a changing Arctic: An Alaskan prototype for multiple users. Polar Geogr., 37, 5-27, https://doi.org/10.1080/ 1088937X.2013.873090.

Fawcett, D., T. Pearce, R. Notaina, J. D. Ford, and P. Collings, 2018: Inuit adaptability to changing environmental conditions over an 11-year period in Ulukhaktok, Northwest Territories. Polar Rec., 54, 119-132, https://doi.org/10.1017/S003224741800027X.

Ford, J., 2019: Changing access to ice, land and water in Arctic communities. Nat. Climate Change, 9, 335-339, https://doi.org/ 10.1038/s41558-019-0435-7.

Fox, S., E. Qillaq, I. Angutikjuak, D. J. Tigullaraq, R. Kautuk, H. Huntington, G. E. Liston, and K. Elder, 2020: Connecting understandings of weather and climate: Steps towards coproduction of knowledge and collaborative environmental management in Inuit Nunangat. Arct. Sci., 6, 267-278, https:// doi.org/10.1139/as-2019-0010.

Furgal, C., and J. Seguin, 2006: Climate change, health, and vulnerability in Canadian northern aboriginal communities. Environ. Health Perspect., 114, 1964-1970, https:/doi.org/ 10.1289/ehp.8433.

Gearheard, S., and Coauthors, 2006: "It's not that simple": A collaborative comparison of sea ice environments, their uses, observed changes, and adaptations in Barrow, Alaska, USA, and Clyde River, Nunavut, Canada. Ambio, 35, 203-211, https://doi.org/10.1579/0044-7447(2006)35[203:INTSAC] 2.0.CO;2.

- M. Pocernich, R. Stewart, J. Sanguya, and H. P. Huntington, 2010: Linking Inuit knowledge and meteorological station observations to understand changing wind patterns at Clyde River, Nunavut. Climatic Change, 100, 267-294, https:// doi.org/10.1007/s10584-009-9587-1.

Gearheard, S. F., L. K. Holm, H. Hunting, J. M. Leavitt, and A. R. Mahoney, Eds., 2013: The Meaning of Ice: People and Sea Ice in Three Arctic Communities. International Polar Institute Press, 365 pp. 
George, J. C. C., H. P. Huntington, K. Brewster, H. Eicken, D. W. Norton, and R. Glenn, 2004: Observations on shorefast ice dynamics in Arctic Alaska and the responses of the Iñupiat Hunting Community. Arctic, 57, 363-374, https://doi.org/ 10.14430/arctic514.

Gilbert, S. Z., D. E. Walsh, S. N. Levy, B. Maksagak, M. I. Milton, J. D. Ford, N. L. Hawley, and R. Dubrow, 2021: Determinants, effects, and coping strategies for low-yield periods of harvest: A qualitative study in two communities in Nunavut, Canada. Food Secur., 13, 157-179, https://doi.org/10.1007/s12571-02001112-0.

Government of Nunavut, 2012: Nunavut infrastructure: Building our infrastructure. Department of Executive and Intergovernmental Affairs Doc., 2 pp., https://www.gov.nu.ca/sites/default/files/files/ FINAL \%20GN\%20Info \%20Package \% 20-\%20Building \% 20Our\%20Infrastructure(1).pdf.

- 2016: Nunavut Emergency Management Annual Report 2015-2016. Department Community and Government Services Rep., 13 pp., https://assembly.nu.ca/sites/default/files/TD-2524(3)-EN-Nunavut-Emergency-Management-Annual-Report2015-2016.pdf.

, 2017a: Nunavut Emergency Management Annual Report 2016. Department Community and Government Services Rep., 5 pp., https://assembly.nu.ca/sites/default/files/TD-94-5(2)-ENNunavut-Emergency-Management-Annual-Report-2016.pdf.

_ 2017 b: Nunavut Emergency Management Annual Report 2017. Department Community and Government Services Rep., 6 pp., https://assembly.nu.ca/sites/default/files/TD-955(2)-EN-Nunavut-Emergency-Management-Annual-Report2017.pdf.

_- 2019: Nunavut Emergency Management Annual Report 2018/19. Department of Community and Government Services Rep., 14 pp., https://www.gov.nu.ca/sites/default/files/cgs_nem_ annual_report_2018-19_feb_17.pdf.

Green, D., B. Jack, and A. Tapim, 2010: Indigenous Australians' knowledge of weather and climate. Climatic Change, 100, 337354, https://doi.org/10.1007/s10584-010-9803-z.

Heyes, S., 2011: Cracks in the knowledge: sea ice terms in Kangiqsualujjuaq, Nunavik. Can. Geogr., 55, 69-90, https:// doi.org/10.1111/j.1541-0064.2010.00346.x.

Inuit Circumpolar Council, 2014: The sea ice never stops-Circumpolar Inuit reflections on sea ice use and shipping in Inuit Nunaat. ICC Rep., 64 pp., https://secureservercdn.net/104.238.71.250/ hh3.0e7.myftpupload.com/wp-content/uploads/Sea-Ice-NeverStops-Final.pdf.

Inuit Tapiriit Kanatami, 2018: National Inuit strategy on research. ITK Rep., 48 pp., https:/www.itk.ca/wp-content/uploads/ 2018/04/ITK_NISR-Report_English_low_res.pdf.

_ 2021: Inuit Nunangat food security strategy. ITK Rep., 56 pp., https:/www.itk.ca/wp-content/uploads/2021/07/ITK_FoodSecurity-Strategy-Report_English_PDF-Version.pdf.

Jeuring, J., M. Knol-Kauffman, and A. Sivle, 2020: Toward valuable weather and sea-ice services for the marine Arctic: Exploring user-producer interfaces of the Norwegian Meteorological Institute. Polar Geogr., 43, 139-159, https:// doi.org/10.1080/1088937X.2019.1679270.

Johnson, N., and Coauthors, 2015: The contributions of communitybased monitoring and traditional knowledge to Arctic observing networks: Reflections on the state of the field. Arctic, 68, 13, https://doi.org/10.14430/arctic4447.

Kaiser, B. A., and Coauthors, 2019: The importance of connected ocean monitoring knowledge systems and communities. Front. Mar. Sci., 6, 309, https://doi.org/10.3389/fmars.2019.00309.
Karetak, J., F. Tester, and S. Tagalik, 2017: Inuit Qaujimajatuqangit: What Inuit Have Always Known to be True. Fernwood Publishing, 268 pp.

Kettle, N. P., S. F. Trainor, and P. A. Loring, 2017: Conceptualizing the science-practice interface: Lessons from a collaborative network on the front-line of climate change. Front. Environ. Sci., 5, 33, https://doi.org/10.3389/fenvs.2017.00033.

—, D. Abdel-Fattah, A. R. Mahoney, H. Eicken, L. W. Brigham, and J. Jones, 2020: Linking Arctic system science research to decision maker needs: Co-producing sea ice decision support tools in Utqiagivik, Alaska. Polar Geogr., 43, 206-222, https:// doi.org/10.1080/1088937X.2019.1707318.

Krupnik, I., C. Aporta, S. Gearheard, G. J. Laidler, and L. KielsenHolm, Eds., 2010: SIKU: Knowing Our Ice, Documenting Inuit Sea-Ice Knowledge and Use. Springer, 445 pp.

Laidler, G. J., J. D. Ford, W. A. Gough, T. Ikummaq, A. S. Gagnon, S. Kowal, K. Qrunnut, and C. Irngaut, 2009: Travelling and hunting in a changing Arctic: Assessing Inuit vulnerability to sea ice change in Igloolik, Nunavut. Climatic Change, 94, 363-397, https://doi.org/10.1007/s10584-008-9512-z.

-, T. Hirose, M. Kapfer, T. Ikummaq, E. Joamie, and P. Elee, 2011: Evaluating the floe edge service: How well can SAR imagery address Inuit community concerns around sea ice change and travel safety? Can. Geogr., 55, 91-107, https:// doi.org/10.1111/j.1541-0064.2010.00347.x.

Lamers, M., P. Duske, and L. van Bets, 2018: Understanding user needs: A practice-based approach to exploring the role of weather and sea ice services in European Arctic expedition cruising. Polar Geogr., 41, 262-278, https://doi.org/10.1080/ 1088937X.2018.1513959.

Lovecraft, A., C. Meek, and H. Eicken, 2013: Connecting scientific observations to stakeholder needs in sea ice social-environmental systems: The institutional geography of northern Alaska. Polar Geogr., 36, 105-125, https://doi.org/10.1080/1088937X.2012.733893.

Masinde, M., 2015: An innovative drought early warning system for sub-Saharan Africa: Integrating modern and indigenous approaches. Afr. J. Sci. Technol. Innov. Dev., 7, 8-25, https:// doi.org/10.1080/20421338.2014.971558.

Nickels, S., C. Furgal, M. Buell, and H. Moquin, 2005: Unikkaaqatigiit: Putting the human face on climate change-Perspectives from Nunavik communities. Inuit Tapiriit Kanatami, Nasivvik Centre for Inuit Health and Changing Environments at Université Laval and the Ajunnginiq Centre at the National Aboriginal Health Organization Doc., 25 pp., https://www.itk.ca/wp-content/ uploads/2016/07/Nunavik.pdf.

Panikkar, B., B. Lemmond, B. Else, and M. Murray, 2018: Ice over troubled waters: Navigating the Northwest Passage using Inuit knowledge and scientific information. Climate Res., 75, 81-94, https://doi.org/10.3354/cr01501.

Pardo, N., H. Wilson, J. N. Procter, E. Lattghi, and T. Black, 2015: Bridging Māori indigenous knowledge and western geosciences to reduce social vulnerability in active volcanic regions. J. Appl. Volcanol., 4, 5, https://doi.org/10.1186/s13617014-0019-1.

Pearce, T., H. Wright, R. Notaina, A. Kudlak, B. Smit, J. Ford, and C. Furgal, 2011: Transmission of environmental knowledge and land skills among Inuit men in Ulukhaktok, Northwest Territories, Canada. Hum. Ecol., 39, 271-288, https://doi.org/ 10.1007/s10745-011-9403-1.

Qikiqtani Inuit Association, 2013: Qikiqtani Truth Commission: Community histories 1950-1975-Pond Inlet. Iqaluit Nunavut Inhabit Media, Inc., Rep., 42 pp., https://www.qtcommission.ca/ sites/default/files/community/community_histories_pond_inlet.pdf. 
Segal, R., R. K. Scharien, F. Duerden, and C. L. Tam, 2020: "The best of both worlds" _ Connecting remote sensing and Arctic communities for safe sea ice travel. Arctic, 73, 461-484, https:// doi.org/10.14430/arctic71896.

Shirley, J., 2006: C-CIARN North-Nunavut community research needs survey: Summary report. Nunavut Research Institute Rep., 24 pp., https://www.nri.nu.ca/sites/default/files/public/ files/c-ciarn_research_needs_survey.pdf.

Statistics Canada, 2016: Census profile, 2016 census Pond Inlet, Hamlet [Census subdivision], Nunavut and Nunavut [Territory]. Accessed 7 July 2021, https://www12.statcan.gc.ca/censusrecensement/2016/dp-pd/prof/details/page.cfm?Lang $=\mathrm{E} \& \mathrm{Geo} 1=$ CSD $\&$ Code $1=6204020 \&$ Geo $2=$ PR\&Code $2=62 \&$ Data $=$ Count $\&$ SearchText $=$ Pond $\%$ 20Inlet $\&$ SearchType $=$ Begins $\&$ SearchPR $=01 \&$ $\mathrm{B} 1=\mathrm{All} \& \mathrm{GeoLevel}=\mathrm{PR} \& \mathrm{GeoCode}=6204020 \& \mathrm{TABID}=1$.

Steiro, V. D., J. C. Ryan, S. W. Cooley, L. C. Smith, B. Dale, A. H. Lynch, and S. Veland, 2021: Changes in sea ice travel conditions in Uummannaq Fjord, Greenland (1985-2019) assessed through remote sensing and transportation accessibility modeling. Polar Geogr., https://doi.org/10.1080/ 1088937X.2021.1938271, in press.

Stewart, E. J., D. Liggett, M. Lamers, G. Ljubicic, J. Dawson, R. Thoman, R. Haavisto, and J. Carrasco, 2020: Characterizing polar mobilities to understand the role of weather, water, ice and climate (WWIC) information. Polar Geogr., 43, 95-119, https://doi.org/10.1080/1088937X.2019.1707319.

Tester, F., and P. Irniq, 2008: Inuit Qaujimajatuqangit: Social history, politics and the practice of resistance. Arctic, 61, 48-61.

Thoman, R. L., Jr., J. Dawson, D. Liggett, M. Lamers, E. Stewart, G. Ljubicic, and M. Knol, 2017: Understanding the creation and use of polar weather and climate information. Bull. Amer. Meteor. Soc., 98, ES3-ES5, https://doi.org/10.1175/BAMS-D16-0195.1.

Walton, D., 2007: Six fish, two birds and four weeks in the wild. Globe and Mail, https://www.theglobeandmail.com/news/national/sixfish-two-birds-and-four-weeks-in-the-wild/article1088139/.

Watt-Cloutier, S., 2015: The Right to be Cold: One Woman's Story of Protecting Her Culture, the Arctic and the Whole Planet. Penguin Canada, 337 pp.

Weatherhead, E., S. Gearheard, and R. G. Barry, 2010: Changes in weather persistence: Insight from Inuit knowledge. Global Environ. Change, 20, 523-528, https://doi.org/10.1016/ j.gloenvcha.2010.02.002.

Wesche, S. D., and M. H. Chan, 2010: Adapting to the impacts of climate change on food security among Inuit in the western Canadian Arctic. EcoHealth, 7, 361-373, https://doi.org/ 10.1007/s10393-010-0344-8.

Wilson, K. J., T. Bell, A. Arreak, and B. Koonoo, 2020: Changing the role of non-Indigenous research partners in practice to support Inuit self-determination in research. Arct. Sci., 6, 127-153, https://doi.org/10.1139/as-2019-0021.

—_, A. Arreak, J. Itulu, G. J. Sikumiut Ljubicic, and T. Bell, 2021: When we're on the ice, all we have is our Inuit Qaujimajatuqangit": Mobilizing Inuit knowledge as a sea ice safety adaptation strategy in Mittimatalik, Nunavut. Arctic, in press.

WMO, 2017: Navigating weather, water, ice and climate information for safe polar mobilities. WMO Doc. WWRP/PPP 5-2017, 84 pp., https://epic.awi.de/id/eprint/46211/1/012_WWRP_ PPP_No_5_2017_11_OCT.pdf. 